\title{
Silphium perfoliatum-A Herbaceous Crop with Increased Interest in Recent Years for Multi-Purpose Use
}

\author{
Dumitru Peni $^{1, *(\mathbb{D}}$, Mariusz Jerzy Stolarski ${ }^{1}{ }^{\mathbb{D}}$, Anna Bordiean ${ }^{1}\left(\mathbb{D}\right.$, Michał Krzyżaniak ${ }^{1}(\mathbb{D}$ and \\ Marcin Dębowski ${ }^{2}$ (D) \\ 1 Department of Plant Breeding and Seed Production, Faculty of Environmental Management and Agriculture, \\ University of Warmia and Mazury in Olsztyn, Plac Łódzki 3, 10-724 Olsztyn, Poland; \\ mariusz.stolarski@uwm.edu.pl (M.J.S.); anna.bordiean@uwm.edu.pl (A.B.); \\ michal.krzyzaniak@uwm.edu.pl (M.K.) \\ 2 Department of Environmental Engineering, Faculty of Geoengineering, University of Warmia and Mazury in \\ Olsztyn, Warszawska 117, 10-719 Olsztyn, Poland; marcin.debowski@uwm.edu.pl \\ * Correspondence: dumitru.peni@uwm.edu.pl
}

Received: 17 November 2020; Accepted: 14 December 2020; Published: 16 December 2020

\begin{abstract}
Silphium perfoliatum is a perennial crop native to North America that has been the subject of increased scientific interest in recent years, especially in Europe. It is drought- and frost-resistant, which makes it suitable for cultivation in Europe on marginal lands that are not used for growing other crops. This review analyzed the distribution and purposes of the cultivation of Silphium perfoliatum worldwide, as well as its biomass yields and characteristics as a feedstock for biogas production and other purposes. A total of 121 scientific publications on Silphium perfoliatum were identified, with the highest number (20 papers) published in 2019. It was found that higher biomass yields can be obtained at higher precipitation levels, with the use of fertilizers and an adequate type of plantation. The mean dry matter yield of Silphium perfoliatum was $13.3 \mathrm{Mg} \mathrm{ha}^{-1} \mathrm{DM}$ (dry matter), and it ranged from 2 to over $32 \mathrm{Mg} \mathrm{ha}^{-1} \mathrm{DM}$. In some countries, Silphium is used as a forage crop mainly due to its high crude protein content (from $4.9 \%$ to $15 \% \mathrm{DM}$ ), depending on the vegetation phase. Silphium perfoliatum is a promising perennial crop in terms of energy and other benefits for biodiversity, soil quality and applications in medicine and pharmacology.
\end{abstract}

Keywords: cup plant; perennial energy crop; energy expenses; biogas; biomass yield

\section{Introduction}

Since climate change is caused mainly due to the wide use of fossil fuels, it is necessary to mitigate their impact and prevent their depletion. Under these conditions, it is very important to replace fossil fuels with renewable energy sources (RES), to stop the increase in greenhouse gases in the atmosphere [1] and reduce pollution caused by burning fossil fuels. Researchers are trying to identify different biomass sources that are acceptable for production, cheap, easy to grow and offer high yields that will be suitable for the commonly used conversion technologies. Moreover, there is a need to adapt some of the possible biomass sources to specific climatic conditions of some regions or try to use local sources. Anaerobic digestion can be seen as the most attractive renewable energy pathway to convert organic material into green fuel [2]. These complex processes provide several additional environmental benefits, since digestate from biogas production can be used as a biofertilizer and its utilization can reduce the amount of fertilizers needed [1,3].

Biomass is considered to be an organic, non-fossil material of biological origin, such as manure, wastewater sludge, food and organic waste, municipal organic waste, animal waste, 
agricultural residues, and forest and industrial wood waste. The biological wastes are classified as a renewable energy resource due to the possibility of the incorporation of solar energy $[4,5]$.

Perennial crops are seen as a promising feedstock for renewable energy technologies $[5,6]$, including biogas production, due to the large amount of biomass that can be obtained from a relatively small area compared to annual crops. Moreover, perennial crops offer other benefits for biodiversity and the environment [7-10].

The Silphium perfoliatum (cup plant) is considered a promising alternative substrate for biogas production [11,12] that could replace the current use of maize silage [13-15]. It is characterized by low production costs and can be grown on less productive or polluted soil [16]. The crop is resistant to winter frost and summer drought and is less dependent on atmospheric precipitation [17]. Moreover, in Central Europe, it is not very susceptible to pests and diseases that affect biomass productivity or yield $[11,18]$. Existing pests are unlikely to limit the production of seeds or biomass of Silphium perfoliatum [19]. In the USA, there have been cases reported of plantation damage caused by larvae, birds and mammals (moths, turkey and deer) [20]. In this case, damage was caused by natural biodiversity factors, which are beyond human control and can occur in every country. Silphium was studied in different countries, for different purposes: as a potential forage crop in New Zealand [21], Ukraine [22], USA [23,24] and Romania [25]; and as a forage crop in Belarus [26], Chile [27], China [28] and Russia [29-33]. In Austria [12], Czech Republic [15] and Poland [34,35], biomass has been investigated for biogas production. It is also being studied for future possible use in Kazakhstan as a forage crop [36]. Another use of Silphium perfoliatum was proposed as a raw material for particleboards that can successfully replace wood and reduce wood shortages [37], which is important for industrial applications. Seeds of Silphium L. species, including S. perfoliatum, S. integrifolium and S. trifoliatum, were studied by using different parameters for different purposes [35]. Silphium perfoliatum was also cultivated as an ornamental plant [25] with high nectar productivity [38-41].

The current review analyzes general interest in the use of Silphium perfoliatum around the world for different purposes over the last 20 years. The existing information on its description, productivity, utilization and chemical composition is summarized, along with energy efficiency and biogas yield, to analyze its use as a promising future RES and a future field of research.

\section{Materials and Methods/Data Collection and Selection}

The current study screened papers for Silphium perfoliatum utilization, energy, biomass production, yielding, biogas yields, etc. The search was conducted by using ScienceDirect, Scopus, Google Scholar and other sources, including Russian websites. The search focused on original papers, research articles, reports and short communiqués issued between 2000 and 2020, mostly in Europe, Asia and North America. The search involved specific keywords: cup plant, Silphium perfoliatum, sylphia, silphium and силь чиа (Russian). A total of 121 papers were identified that matched the search described above. Most of these papers were published in English (101), but also in Russian (12), Polish (3), German (4) and French (1). The papers were scanned for a description of Silphium perfoliatum and different species/subspecies of Silphium, their use around the world and the different requirements for planting. Information on biomass productivity in different years from different locations, soil types and environmental conditions was collected. Moreover, information about the biomass quality, chemical composition and biogas properties of Silphium perfoliatum studied by researchers was gathered. The paper also presents economic and energy information found in various research papers on Silphium perfoliatum biomass production.

\section{Results and Discussion}

\subsection{Scientific Papers Related to Silphium perfoliatum}

An increased interest in the use of Silphium perfoliatum was observed from 2000 to June 2020 (Figure 1). In 2000, only four papers were found that discuss Silphium perfoliatum, and there were no 
papers in two years (2001 and 2006). The number of publications on this topic increased to 12 published papers in 2015 and 2017. The maximum number of such papers (20) was released in 2019, and they continue to be published in 2020. Over the studied period, a total of 118 scientific publications were identified related to Silphium perfoliatum.

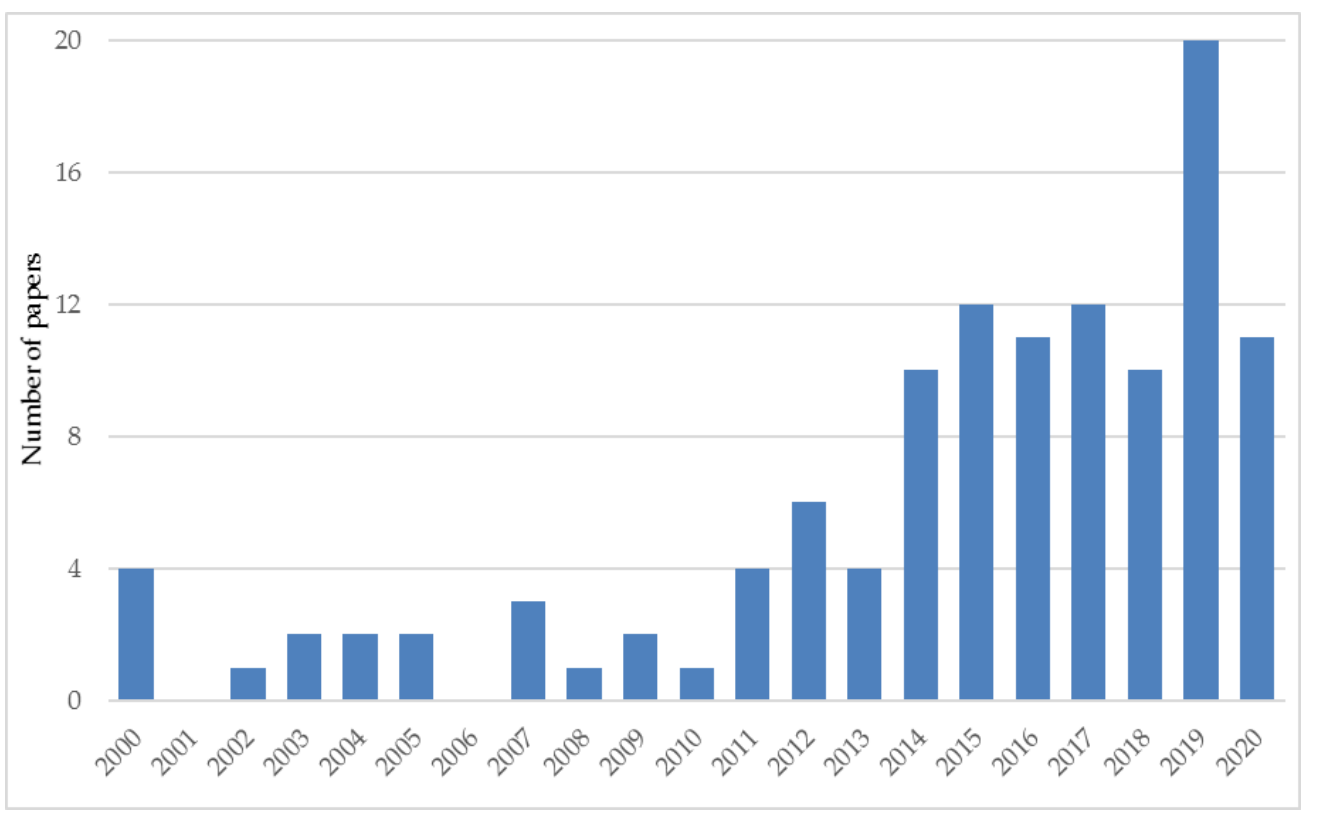

Figure 1. The number of peer-reviewed Silphium perfoliatum-related scientific papers in 2000-2020.

The general interest of these papers was mostly based on the use of Silphium perfoliatum as feed for livestock (mostly in post-Soviet Union countries) and as a possible future RES due its high biomass yield. There is different interest in using Silphium perfoliatum around the world. There were 96 papers published in Europe, including Russia, in the selected period (Figure 2). The highest number of research papers was found in Germany (31 papers), Poland (30 papers) and Lithuania (11). Some studies were also conducted in Russia (7), Republic of Moldova (4), Belarus (4), Austria (3) and Czech Republic (3), as well as in Romania, Ukraine, Kazakhstan and The Netherlands (1). A high interest/number of papers was also found in the USA (12 papers), which was due to the North American origin of Silphium perfoliatum $[42,43]$. There were seven papers found from China, while Chile and Egypt published one paper each.

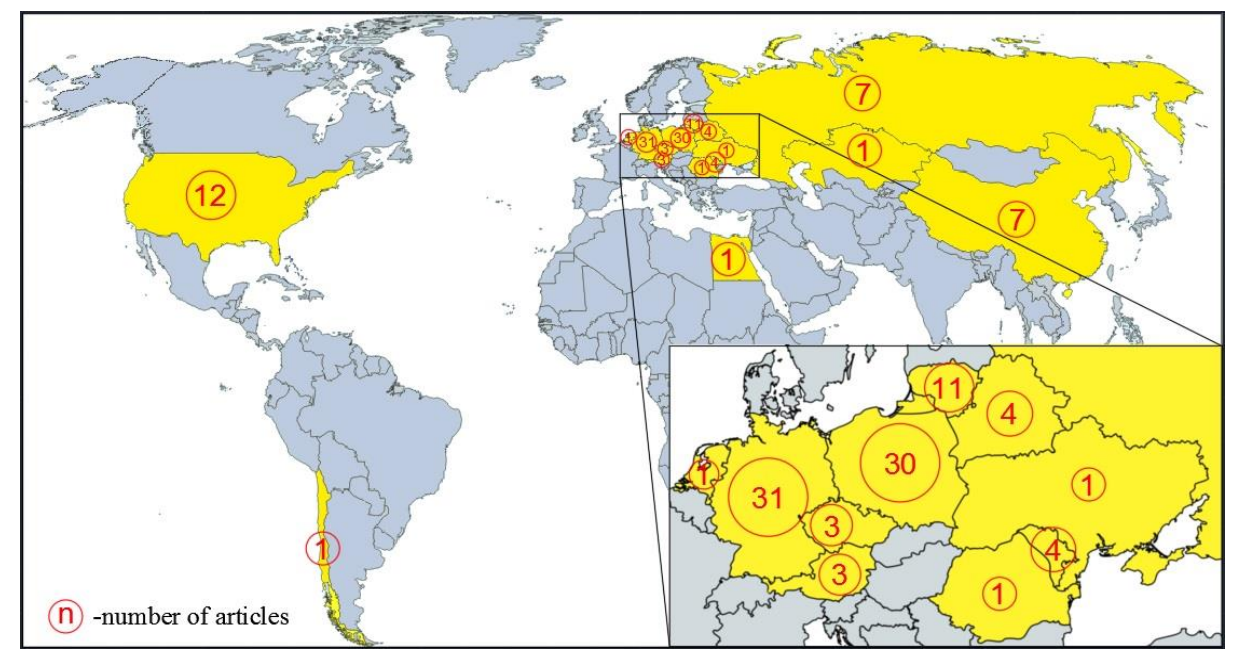

Figure 2. Map of published Silphium perfoliatum-related scientific articles, by country, in 2000-2020. 


\subsection{Description and Origin}

Silphium L. is a genus of the sunflower family (Asteraceae) found in the woodlands and prairies of North America [42,43]. The name of the Silphium genus originates from the Greek silphion and means a plant secreting resin, used earlier by Hippocrates [44]. In the cited work, it is mentioned that Silphium was imported to Europe around the 18th century as an ornamental plant. The best-known species are Silphium perfoliatum L., Silphium trifoliatum L., Silphium integrifolium Michx and Silphium laciniatum L., although there are more varieties and subspecies [45-47].

The Silphium perfoliatum species is a part of Heliantheae and is a perennial herb, also called a cup plant, Indian cup [48], Rosinweed [49], sylph or cap-plant [46]. It is native to the eastern half of the USA and Canada and grows on moist soils [50]. It is tolerant of low winter temperatures and slightly drained soil [27,28]. Some species of Silphium can grow from $1.8 \mathrm{~m}$ in May to $2.5 \mathrm{~m}$ in July [46,47] in university/botanical gardens $[46,47,51]$ with short winters and warm springs, moderate precipitation levels and on good-quality black soils (chernozems).

In a study conducted in the USA, the genetic differentiation between five populations of Silphium perfoliatum was verified. The aim was to identify the genetic variation between populations and identify the traits related to higher biomass yield and methane productivity. It was found that four plant populations (Russia, USA, East Germany and Northern Europe) have almost similar genetic characteristics and their yields are almost the same. A fifth plant population from Ukraine had a lower biomass yield, methane hectare yield (MHY) and represented a clear example of population stratification [52].

The most recommended method of cultivating Silphium perfoliatum is by seedlings, but this method is still limited by high costs. The best method is to plant seedlings by using the pattern of $70 \times 30 \mathrm{~cm}$ [53]. Some experimental studies used a plant density of 20,000 plants ha ${ }^{-1}$ with a $100 \mathrm{~cm}$ distance between each row and $50 \mathrm{~cm}$ distance between the seedlings in each row $[17,54,55]$. A similar plant density of 28,000 plants ha ${ }^{-1}$ can be obtained using the $100 \times 40$ and $90 \times 40 \mathrm{~cm}$ method $[45,56]$. Another pattern of planting was used by Stolarski et al. [18,57], who manually planted seedlings, leaving $100 \mathrm{~cm}$ between rows and strips [18] and obtained 10,000 plants ha ${ }^{-1}$. Other studied plant densities, including 35,000 and 70,000 plant ha ${ }^{-1}$, were described by Stankevich et al. [58].

To use Silphium perfoliatum as a substrate for biogas, it is necessary to increase the cultivated area. As planting by seedlings is the most expensive agricultural operation, plant cultivation by sowing was also studied. It was proposed to improve the seeder, as well as to place seeds at least $15 \mathrm{~mm}$ deep in soil to prevent them from drying out. It is necessary to cover seeds by using different types of rollers for a more precise sowing, but in a way which avoids compromising germination [59]. It is also necessary to improve seed quality to increase productivity [60]. The size of the seed was found to be important for uniform sowing to extend the period of a Silphium perfoliatum plantation use (over 10 years). This is important for the improvement/optimization of sowing precision and for choosing the right seeder $[60,61]$.

Some studies involved experiments using seed sterilization and micropropagation processes in improving sowing material [62-64]. Micropropagation also eliminates the possibility for Silphium perfoliatum to become invasive, due to achenes (fruits) that do not contain seeds and do not present a danger to native biodiversity [65]. For some purposes (e.g., pharmaceutical), it is recommended that all raw material should be standardized and maintained under controlled in vitro conditions. Different component concentrations were tested by using drip irrigation, which influenced the height of plants, the length and number of internodes, the number of flowers, leaf quantity and area, fresh weight of the shoots and stalk thickness $[64,66]$, which are all important when extracting active components for the purposes listed above. There are reviews [67] detailing information on the metabolites and phytochemicals contained in Silphium perfoliatum parts. Many of the studies on these phytochemicals were conducted in Poland $[34,44,68]$.

A study conducted in Poland found that seed production per Silphium perfoliatum plant is higher compared to other Silphium species [35]. It is the most valuable species for seed productivity. 
It produced $19.02 \mathrm{~g}$ of seeds per shoot, $185.06 \mathrm{~g}$ of seeds per plant and the weight of 1000 seeds was $21.45 \mathrm{~g}$ [35]. The application of nitrogen fertilizers in soil $\left(\mathrm{N}_{90}\right.$ and $\left.\mathrm{N}_{120}\right)$ in an experiment involving sowing seeds produced a higher yield of seeds, ranging from 0.36 to $0.39 \mathrm{Mg} \mathrm{ha}^{-1}$ [53].

The germination capacity of Silphium perfoliatum seeds is high and is influenced by environmental conditions, such as light, temperature, pretreatment of seeds and pre-chilling. The germination capacity can be considerably increased when seeds are pretreated with a chemical solution $\left(\mathrm{GA}_{3}\right.$ and $\left.\mathrm{KNO}_{3}\right)$ rather than only supplied with water for germination. The same study found that the best germination was achieved when a dark-light cycle (12:12) was applied with a temperature alternating between 20 and $30^{\circ} \mathrm{C}$, preceded by wet stratification, for seven days, at $0{ }^{\circ} \mathrm{C}$ [12]. Even though it is recommended to plant Silphium by using seedlings, to reduce costs, the planting by sowing can also be used. Another study found that the best seed germination results can be obtained by using pelleted seeds. In the planting of Silphium by sowing, pelleted seeds were pretreated with gibberellic acid. The most recommended time of year for sowing Silphium seeds in Central Europe is the end of April [69].

\subsection{Utilization and Benefits/Advantages of Silphium perfoliatum}

Silphium genus was used by native North American tribes for different medicinal purposes [48]. Due to the presence of active compounds in Silphium perfoliatum, its application in the production of drugs [70,71] and cosmetics is currently being investigated [72]. Some active components from Silphium leaves in combination with other chemical solutions can even contribute to improving the germination of common wheat seeds (Tritium aestivum L.) [73]. Around 16 compounds have now been isolated from Silphium perfoliatum for different pharmacological uses [48,74]. Some of them have shown immunosuppressive activity [48], with potential use in organ transplants. In addition, some extracts from leaves, inflorescences and rhizomes have been separated and found to display antibacterial activity on Gram-positive and Gram-negative bacteria [44]. The antifungal activity of $5 \%$ and $10 \%$ Silphium perfoliatum leaf extracts, that was applied on different types of fungi (Alternaria alternata, Botrytis cinerea, Colletotrichum coccodes, Fusarium oxysporum, Penicillium expansum and Trichoderma harzianum) found usually on some plants [75] was tested as an antifungal solution for pepper (Capsicum annuum L.). It was found that different plant parts, such as leaves, inflorescences and rhizomes contain phenolic acids (caffeic, p-coumaric, ferulic, vanillic, etc.). Due to their antioxidant activity, Silphium perfoliatum may offer medicinal benefits [76-78] as well as provide essential oils $[68,79,80]$. A very detailed analysis was recently performed on the active compounds of different Silphium perfoliatum parts [80,81]. These compounds (L-ascorbic acid; chlorophyll a and b; tannins; microelements- $\mathrm{K}, \mathrm{Ca}, \mathrm{Mg}, \mathrm{Zn}, \mathrm{Fe}, \mathrm{Mn}$ and Se) are of interest to the pharmaceutical and food industries [80].

Other studies have analyzed the concentration of various compounds in Silphium perfoliatum that are important for fodder purposes [34]. There are also studies that have investigated Silphium perfoliatum silage [24] and its digestibility [23] as forage for livestock. In a study conducted in Moldova, it was found that a variety of Silphium perfoliatum (Vital variety) could be recommended for use as fodder for livestock, due to its characteristics (high protein content) and high biomass yield [46,47]. The same species was tested for renewable energy purposes, such as feedstock for biogas and briquette production [51,82]. It was also found that the presence of pollen and nectar on the Silphium perfoliatum disc florets has a positive effect on biodiversity $[39,40,83]$. It is also recommended for remediation of intensively managed soils [84-88] due to an increasing number of earthworms and long periods without any agro-technical work (plowing, rest and cultivation) [85]. Likewise, these fields became a home for arthropods [89] and can be an option for honeybees due to the long flowering period of the studied plant [38].

It should be emphasized, however, that prior to the establishment of a Silphium perfoliatum plantation (as in the case of other perennial plants) it is very important to adequately prepare the cultivation site, which includes removal of perennial weeds and soil cultivation. In the first year of the plantation, particular attention should be paid to weed removal by two or three mechanical weedings. Moreover, due to its high resistance in severe conditions (winter frosts, drought and 
acidic soils), a Silphium perfoliatum field does not require recultivation for 20 years. Other advantages of using a field for longer periods include reduced expenses on pesticides or herbicides due to shadow created by leaves. The annual litter residues (leaves) and the extensive root system of Silphium perfoliatum enrich valuable humus in the soil and prevent soil erosion. However, soil moisture significantly influences the density/biomass of the roots. Thus, in the case of soil excess moisture, the largest branching of roots (biomass roots) were found in the lower layers of soil, with $32 \%$ of roots compared to $12.3 \%$ of roots found in soil without excess moisture [90]. Therefore, soil moisture plays an important role in increasing the Silphium perfoliatum root biomass [91]. It was found that the biodiversity of soil is improved and regenerated on Silphium plantations $[7,84,86]$. Due to the presence of earthworms, for example, water infiltration in the soil can be improved [92]. One study found that the degradation of litter from Silphium leaves by insects, worms and other larvae help to increase nitrogen levels in soils (depending on the soil type) [93]. The effect of fertilizers on Silphium perfoliatum fields was also investigated. The use of lime and $\mathrm{N}$ fertilizers for Silphium perfoliatum plantations has a positive impact on soil. It was found that the soil under Silphium perfoliatum accumulated a high concentration of $C_{\text {tot }}, N_{\text {tot }}$ and $S_{\text {tot }}$ in soil layers, due to improving the Silphium root system (especially by liming) [94]. The abundant flowering from July to September promotes insect species and pollinators $[39,40,84,89]$, which are vital insects for the world economy. It was established that although the Silphium perfoliatum is resistant to drought, the amount of nectar sugar obtained per hectare depends on the rainfall amount. Thus, insects more often visit plantations with higher soil moisture, e.g., that are irrigated with a higher water level $\left(58 \mathrm{~kg} \mathrm{ha}^{-1}\right)$, than plantations with lower soil moisture levels (rainfed plots) $\left(20 \mathrm{~kg} \mathrm{ha}^{-1}\right.$ ) [39]. It was also found that Silphium is a suitable permanent catch crop (melliferous plant) [95] and that it may become infested by fungi such as Ascochyta silphia (which can be found on Silphium perfoliatum leaves) [96]. This can be prevented by careful observation over time, without using any protective measures, but only by removing the infected crop [95]. However, in a recent study [20] conducted in North Dakota, the authors found the activity of the giant eucosma moth, Eucosma giganteana (Riley), which can inflict serious damage on a plantation. At the investigated sites, $25 \%$ of the plants were affected by the moth larvae and the biomass yield was affected in a similar proportion. These results depend mostly on the location of the sites/plantations. Some sites were situated on moist soils and some on soil with lower precipitation. Thus, it was found that larvae size depends on Silphium shoot size which, in turn, depends on soil moisture [20]. A study in Lithuania, ranked Silphium perfoliatum in third place as one of the most promising energy crops from a list of 22 annual and perennial crops (photosynthesis type C4 and C3) with low environmental pressure, suitable for the Lithuanian climate. The studied crops were evaluated by using a multi-criteria framework, such as photosynthesis type, soil carbon sequestration, erosion control, water adaptation, $\mathrm{N}$ input requirement and dry matter [97].

Silphium perfoliatum can be used for phytoremediation of soil polluted with heavy metals, such as $\mathrm{Cd}$, which do not influence the total biomass and could be seen as a good candidate for phytostabilization [16]. The concentration of heavy metals in Silphium perfoliatum is important when it is used as a forage crop and must meet food standards concerning heavy metal contents. The influence of heavy metals on the yield of overground biomass of Silphium perfoliatum was investigated in Polish studies [98]. Different heavy metal concentrations were applied on Silphium plots. The value of the overground biomass yield ranged from $12.3 \%$ to $23.1 \%$. It was also found that some Silphium overground parts met the food standards for heavy metal pollution (chromium), but some did not (manganese), depending on applied doses [98]. Nevertheless, the use of biochar from Silphium perfoliatum phytoremediation is safe when high-temperature pyrolysis $\left(750^{\circ} \mathrm{C}\right)$ is used for production processes to reduce the leaching risk of potentially toxic metals such as $\mathrm{Zn}, \mathrm{Cd}$ and $\mathrm{Pb}$ [99]. The use of Silphium perfoliatum as a renewable energy source to produce pellets and briquettes was also studied, particularly their quality and composition [82,100-102].

Several studies have analyzed the best conditions for growing Silphium perfoliatum as feedstock for biogas production [11,12,103]. It is also seen as a promising alternative substrate for silage 
maize, due to its reduced agricultural requirements, which enable it to be grown on marginal or less productive soil [16]. Growing Silphium perfoliatum reduces the soil compaction and improves regional biodiversity [85-87].

\subsection{Silphium perfoliatum Yields}

\subsubsection{Biomass Yields}

The possibility of increasing the volume of biomass to meet energy needs has been widely studied [104]. It was estimated that when planting Silphium perfoliatum with $70 \mathrm{~cm}$ between rows

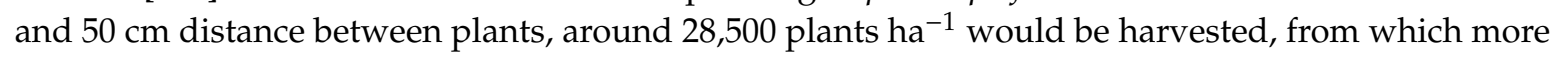
than $40 \mathrm{Mg} \mathrm{ha}^{-1}$ fresh matter (FM) of biomass would be obtained $15 \mathrm{Mg} \mathrm{ha}^{-1}$ dry matter (DM) [105]. In other studies, the yield of green biomass of Silphium perfoliatum at the end of the flowering period was $62.8 \mathrm{Mg} \mathrm{ha}^{-1} \mathrm{FM}, 24.6 \% \mathrm{DM}$, resulting in $15.4 \mathrm{Mg} \mathrm{ha}^{-1} \mathrm{DM}$ [15]. A six-year experiment in Poland (2012-2017) on different types of biomass, including Silphium perfoliatum, found that the results of fresh mass yield were higher in the second year of growing and increased in 2016 and 2017, when the highest yields were obtained of all six years [106].

Silphium perfoliatum is a tolerant plant in environmentally unfavorable conditions [27]. However, good soil quality is necessary to achieve high biomass yield [17,107]. In Germany, yields were tested depending on the different origin (regions/continents) of the Silphium perfoliatum seeds. The most representative features/traits that influence the growth and yield were tested. It was found that there are some differences between the dry matter yield (DM) (from 13.6 to $17.2 \mathrm{Mg} \mathrm{ha}^{-1} \mathrm{DM}$ ) and other biomass traits. The lowest yield was achieved from Silphium seeds from Ukraine. It was assumed that the yield would be lower because the different development of the plant due to climate/environmental factors, as well as the different field of use (since it is used more as a forage crop it has features of a forage crop and less for biogas production and energy purposes) [52]. In another study, the biomass yield of progenies of 33 half-sib families of Silphium perfoliatum were tested in the USA. The yields showed different values in three consecutive years of growth. In the second year, the mean biomass yield was considerably lower than the first and third years (first $=4.7-7.5 \mathrm{Mg} \mathrm{ha}^{-1} \mathrm{DM}$; second $=1.5-3.4 \mathrm{Mg} \mathrm{ha}^{-1} \mathrm{DM}$; third $=5.2-10.5 \mathrm{Mg} \mathrm{ha}^{-1} \mathrm{DM}$ ). It is well-known that yields are usually higher in second and subsequent years, as compared to the first year of cultivation [45]. Another study observed that biomass yield was higher during earlier harvesting (at the end of August (17.2 Mg ha $\left.{ }^{-1} \mathrm{DM}\right)$ and two weeks later $\left(17.1 \mathrm{Mg} \mathrm{ha}^{-1} \mathrm{DM}\right)$ ) and can decrease significantly when harvesting was conducted two weeks later (end of September and mid-October) (15.6 and $13.0 \mathrm{Mg} \mathrm{ha}^{-1} \mathrm{DM}$, respectively) [14]. In other field research conducted in Dagestan (Russia), the highest biomass yield was harvested in the third year of growth $\left(27.9 \mathrm{Mg} \mathrm{ha}^{-1} \mathrm{DM}\right)$ and the lowest was in the fourth year of growth $\left(21.7 \mathrm{Mg} \mathrm{ha}^{-1} \mathrm{DM}\right.$ ) (sum of two harvests in June and the end of September to the beginning of October) [29].

Figure 3 presents the biomass yield of Silphium perfoliatum in the ten countries analyzed in the current review [13-15,17,20,27,29,33,36,41,54,86,99,102,107-114]. The lowest dry matter yield was found in a study from the USA (1.6 Mg ha $\left.{ }^{-1} \mathrm{DM}\right)$ and Lithuania $\left(4.4 \mathrm{Mg} \mathrm{ha}^{-1} \mathrm{DM}\right)$. The highest yield was obtained in a study conducted in Russia (32.1 $\left.\mathrm{Mg} \mathrm{ha}^{-1} \mathrm{DM}\right)$. High yields were also found in Poland (26.6 Mg ha $\left.{ }^{-1} \mathrm{DM}\right)$, Chile (22.3 $\left.\mathrm{Mg} \mathrm{ha}^{-1} \mathrm{DM}\right)$ and Lithuania (21.9 $\left.\mathrm{Mg} \mathrm{ha}^{-1} \mathrm{DM}\right)$. The mean dry matter yield of Silphium perfoliatum from the presented studies was $13.3 \mathrm{Mg} \mathrm{ha}^{-1} \mathrm{DM}$.

Although biomass yield can be influenced by planting density, the relationships are unclear because of other important factors. A study conducted in the USA found that higher planting density $\left(68,000\right.$ plants ha $\left.{ }^{-1}\right)$ produced higher biomass yields $\left(14.2 \mathrm{Mg} \mathrm{ha}^{-1} \mathrm{DM}\right)$ than lower planting density $\left(17,000\right.$ plants ha ${ }^{-1}$ yielded $\left.10.8 \mathrm{Mg} \mathrm{ha}^{-1} \mathrm{DM}\right)$. Other results were obtained in another study conducted by the same researchers, in which the second year produced a very low biomass yield. The reported biomass yield value from all three density sites $\left(17,000,34,000\right.$ and 68,000 plants ha $\left.{ }^{-1}\right)$ for the first year (2011) was 7.5 $\mathrm{Mg} \mathrm{ha}^{-1} \mathrm{DM}$ and $1.6 \mathrm{Mg} \mathrm{ha}^{-1} \mathrm{DM}$, respectively (2012) (the mean 
for all densities) [20]. However, the highest yields obtained in Germany (17.2 $\left.\mathrm{Mg} \mathrm{ha}^{-1} \mathrm{DM}\right)$ were from a density of 40,000 plants ha ${ }^{-1}$ [52] and in Lithuania (21.9 $\left.\mathrm{Mg} \mathrm{ha}^{-1} \mathrm{DM}\right)$ from a density of 20,000 plants ha ${ }^{-1}[54]$.

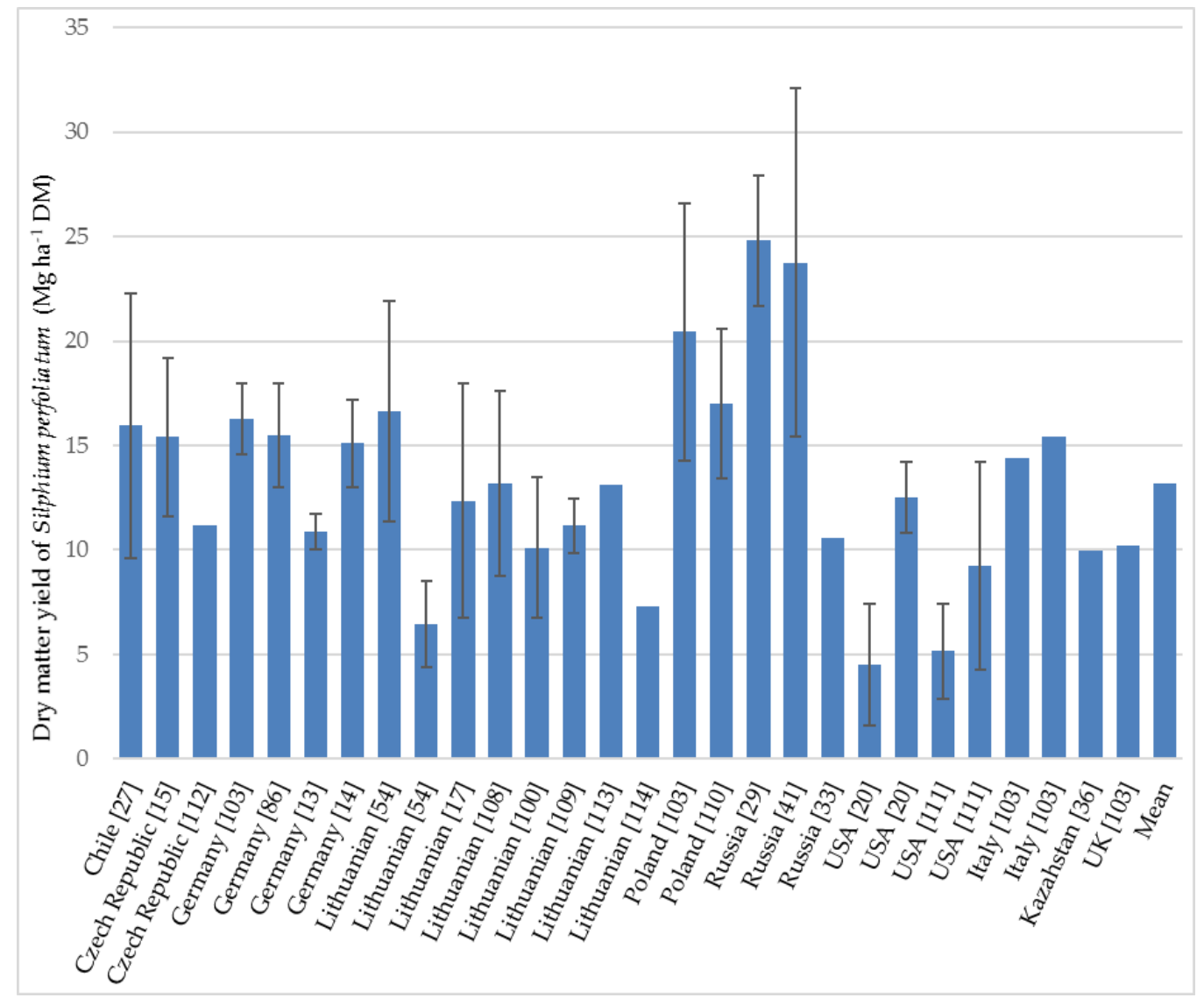

Figure 3. Dry matter yield of Silphium perfoliatum in different countries influenced by different factors (fertilizers, growing areas and different years of growth) and the mean for all countries; error bars represent the minimum and maximum values.

Table 1 presents the different biomass yields depending on the year of growth of Silphium perfoliatum. It can be seen that harvested yields depend on the soil, climatic and weather conditions, as well as other environmental factors in each country/region. The harvesting strategy implemented (once or twice per growing season) in some studies provides information on the choice of the optimal method for harvesting and the harvest period (month).

In a study conducted in Chile [27], the dry matter yield obtained in the first year ranged from 9.6 to $22.3 \mathrm{Mg} \mathrm{ha}^{-1} \mathrm{DM}$, and for the second year, it ranged from 14.6 to $19.4 \mathrm{Mg} \mathrm{ha}^{-1} \mathrm{DM}$, under similar climatic conditions (Table 1). It was observed that, with a longer growing period, the yields were higher and the plants were taller [27]. The cultivation of Silphium in combination with other crops was also tested, to increase the biomass yields [32,111].

Testing different fertilizers is not uncommon and is very often used to increase the Silphium perfoliatum DM yield. The use of lime fertilizers $\left(\mathrm{CaCO}_{3}\right)$ has shown good results for dry matter yield $[17,54,100,109,113]$. Jasinskas et al. [17] showed that lower soil acidity increased the amount of dry biomass yield. The use of fertilizers $\left(6 \mathrm{Mg} \mathrm{ha}^{-1} \mathrm{CaCO}_{3}\right)$ to increase soil $\mathrm{pH}$ when planting on acid soil $\mathrm{pH}(4.2-4.4)$ obtained $11.8 \mathrm{Mg} \mathrm{ha}^{-1} \mathrm{DM}$ and increased to $15.0 \mathrm{Mg} \mathrm{ha}^{-1} \mathrm{DM}$ when the soil $\mathrm{pH}$ was 5.6-5.7 [17]. Lime fertilizers also increased the DM productivity of Silphium perfoliatum (by $15.5 \%$ in the first year, $44.2 \%$ in the second year and $22.9 \%$ in the third year) [54,115]. Other studies averaged $22.7-27.3 \%[100,109,113]$. Liming considerably increases dry matter productivity from the 
first year, at 4.4-8.5 $\mathrm{Mg} \mathrm{ha}^{-1} \mathrm{DM}$, to $11.37-21.9 \mathrm{Mg} \mathrm{ha}^{-1} \mathrm{DM}$ in the second year [54]. Similar results were obtained in other Lithuanian studies $[100,109,113]$. Another study assessed the influence of the application of sewage sludge on the biomass yield on Silphium plantations. Thus, the application of $45 \mathrm{Mg} \mathrm{ha}^{-1}$ of granulated sewage sludge showed the best results (10.4 $\mathrm{Mg} \mathrm{ha}^{-1} \mathrm{DM}$ average yield), compared to an application of a dose of $90 \mathrm{Mg} \mathrm{ha}^{-1}$, which produced $9.3 \mathrm{Mg} \mathrm{ha}^{-1} \mathrm{DM}$ yield. However, this yield was better than the yield obtained with the use of mineral fertilizers $\left(\mathrm{N}_{60} \mathrm{P}_{60} \mathrm{~K}_{60}\right) 7.3 \mathrm{Mg} \mathrm{Ma}^{-1}$ and from control plots $5.9 \mathrm{Mg} \mathrm{ha}^{-1}$ [108]. The application of $120 \mathrm{~kg} \mathrm{ha}^{-1}$ of $\mathrm{N}$ fertilization increased the biomass yield from 11.0 to $15.0 \mathrm{Mg} \mathrm{ha}^{-1} \mathrm{DM}$ (by 26.7\%) [17].

A study using Albeluvisols and Fluvisols also applied fertilization by liming and $\mathrm{N}$ fertilizers, and it was found that liming did not result in a significant influence on stem numbers per plant, which was completely different for $\mathrm{N}$ fertilizers, which produced 5.7 stems per plant in the first year of growth, and up to 12.2 stems per plant in subsequent years. A German study by Mueller and Dauber [83] reported similar results of 6.3 stems per plant on average (1-15 stems), while Polish researchers reported 10-25 stems, which increased in subsequent years [101]. It was also found that Silphium perfoliatum biomass productivity (FM and DM yields) was lower in the first harvest year (19.2 $\mathrm{Mg} \mathrm{ha}^{-1} \mathrm{FM}$ and $6.7 \mathrm{Mg} \mathrm{ha}^{-1} \mathrm{DM}$, respectively), but increased significantly in the next two years (45.2 $\mathrm{Mg} \mathrm{ha}^{-1} \mathrm{FM}$ or $13.5 \mathrm{Mg} \mathrm{ha}^{-1} \mathrm{DM}$, on average) for the control Silphium perfoliatum plantation (no liming and no nitrogen) [55]. The biomass yield of Silphium perfoliatum in some cases showed better results than maize. On different types of soils that are predisposed to compaction (e.g., stagnosoils, planosols and related soils), Silphium perfoliatum biomass yield was considerably higher in the second year of harvest, when maize showed a considerably lower biomass yield [87].

Table 1. Dry matter yield of Silphium perfoliatum in different years of growth.

\begin{tabular}{|c|c|c|c|c|}
\hline $\begin{array}{c}\text { Year of } \\
\text { Harvesting }\end{array}$ & $\begin{array}{c}\text { Yield } \\
\left(\mathrm{Mg} \mathrm{ha}^{-1} \mathrm{DM}\right)\end{array}$ & Country & Observations and Harvesting Details & Reference \\
\hline \multirow{6}{*}{ 1st year } & 22.3 & Chile & $\begin{array}{l}\text { Chahuilco site (Trumao soils): very fertile } \\
\text { acidic soils, pH 5.6, high Al and } \mathrm{Mn} \\
\text { concentration, } 18 \% \text { organic matter. } \\
\text { Average rainfall } 1303 \mathrm{~mm} \text {. Harvested at } \\
\text { flower initiation. }\end{array}$ & [27] \\
\hline & 9.6 & Chile & $\begin{array}{l}\text { La Unión site (Red clay soils): } \mathrm{pH} 5.2, \\
\text { organic matter } 8.0 \% \text {, suffered extreme water } \\
\text { deficit during the summer season. } \\
\text { Average precipitation was } 1277 \mathrm{~mm} \text {. } \\
\text { Harvested at flower initiation. }\end{array}$ & [27] \\
\hline & $10.0 *-15.5^{* *}$ & Germany & $\begin{array}{c}\text { Basic fertilization and nitrogen fertilizers. } \\
\text { The values depend on the watering regime. } \\
\text { Harvest on different dates, depending on } \\
\text { watering: August. }\end{array}$ & {$[13]$} \\
\hline & $13.0^{* * *}-17.2^{*}$ & Germany & $\begin{array}{l}\text { Soil of experimental fields was Cambisol with } \\
\text { a heavy loam texture overlaid with loess loam. } \\
\text { Average precipitation } 591 \mathrm{~mm} \text { (2011) and } \\
727 \mathrm{~mm} \text { (2012). }\end{array}$ & [14] \\
\hline & $4.4-8.5$ & Lithuania & $\begin{array}{l}\text { The values of DM yields differ due to the } \\
\text { amount and types of fertilization: by liming } \\
\text { and nitrogen treatments. Average precipitation } \\
\text { during the vegetation period } 437 \mathrm{~mm} \text {. } \\
\text { Harvest at maturity stage on September } 16 \text {. }\end{array}$ & [54] \\
\hline & 7.5 & USA & $\begin{array}{l}\text { Mean biomass for three planting densities } \\
\left(17,00034,000 \text { and } 680,000 \text { plants ha }{ }^{-1}\right) \text { at } \\
\text { Brookings on soil considered marginal for } \\
\text { conventional crop production due to poor } \\
\text { drainage. No fertilizer, previous planted crop } \\
\text { was soybean (Glycine max L. Merr.) with } \\
\text { long-term rotation with wheat } \\
\text { (Triticum aestivum L.). Planting was executed } \\
\text { one year earlier in June by seedlings (2010). } \\
\text { Harvesting time: in October. }\end{array}$ & {$[20]$} \\
\hline
\end{tabular}


Table 1. Cont.

\begin{tabular}{|c|c|c|c|c|}
\hline $\begin{array}{c}\text { Year of } \\
\text { Harvesting }\end{array}$ & $\begin{array}{c}\text { Yield } \\
\left(\mathrm{Mg} \mathrm{ha}^{-1} \mathrm{DM}\right)\end{array}$ & Country & Observations and Harvesting Details & Reference \\
\hline \multirow{9}{*}{ 2nd year } & 19.4 & Chile & Chahuilco site (see above). & [27] \\
\hline & 14.6 & Chile & La Unión site (see above). & [27] \\
\hline & 17.8 & Chile & $\begin{array}{l}\text { Nochaco site (Nadi soils): iron and aluminum } \\
\text { hardpan layer between the soil, } \mathrm{pH} 5.4 . \\
\text { Average rainfall } 1420 \mathrm{~mm} \text {, dry period } \\
\text { 1-2 months. Harvested at flower initiation. }\end{array}$ & [27] \\
\hline & $11.7^{*}-16.8^{* *}$ & Germany & $\begin{array}{l}\text { The values depend on the watering regime } \\
\text { (see from the first year). }\end{array}$ & [13] \\
\hline & $\begin{array}{l}13.4-15.7^{* * * *} \\
19.4-21.7^{* * * *}\end{array}$ & Poland & $\begin{array}{l}\text { The experiment was conducted on light } \\
\text { rust-brown sandy soil of poor rye complex. } \\
\text { Average rainfall during the growing season } \\
\text { was } 359 \mathrm{~mm} \text {. }\end{array}$ & [110] \\
\hline & $11.4-21.9$ & Lithuania & $\begin{array}{l}\text { Different types and rates of fertilization. } \\
\text { Average precipitation during the growing } \\
\text { season was } 620 \mathrm{~mm} \text {. Plants planted in } 2008, \\
\text { the first harvest was in } 2009 \text {, the second } \\
\text { harvest was on } 30 \text { September } 2010 .\end{array}$ & [54] \\
\hline & 1.6 & USA & Brookings site (see above). & [20] \\
\hline & $10.8-14.3$ & USA & $\begin{array}{l}\text { Soil at Arlington location: Huntsville silt loam } \\
\text { (fine-silty, mixed, mesic Cumulic Hapludoll in } \\
\text { a low-lying area with a capability class of II } \\
\text { because of potential flood damage from water } \\
\text { retention. Nitrogen fertilizer ( } 180 \mathrm{~kg} \mathrm{~N} \mathrm{ha}^{-1} \text { ). } \\
\text { The previous crop was alfalfa } \\
\text { (Medicago sativa L.) Cultivation was in June } \\
\text { 2010. Harvesting time: in September } 2011 \text {. }\end{array}$ & [20] \\
\hline & $\begin{array}{c}1.8 \\
7.4-10.8\end{array}$ & USA & $\begin{array}{l}\text { The experiment was conducted at two different } \\
\text { sites on prime and marginal cropland } \\
\text { (Brookings and Arlington) with a well-detailed } \\
\text { description of soil. Lower value was obtained } \\
\text { on marginal cropland at Brookings } \\
\text { (2013-second year) due to severe drought } \\
\text { during the } 2012 \text { growing season. } \\
\text { Hand-harvesting in November. }\end{array}$ & [111] \\
\hline \multirow{4}{*}{ 3rd year } & $19.1-20.6$ & Poland & $\begin{array}{l}\text { Harvesting was conducted in the second (2017) } \\
\text { and third years (2018) of growth. }\end{array}$ & [110] \\
\hline & $8.8-17.6$ & Lithuania & $\begin{array}{l}\text { The experiment was started in } 2013 \text {. Soil of the } \\
\text { experimental site was naturally acid moraine } \\
\text { loam Bathygleyic Dystric Glossic Retisol. } \\
\text { Different treatments were tested: not fertilized, } \\
\text { fertilized N60P60K60, and fertilized with } \\
\text { different amounts of granulated sewage sludge } \\
\left(45 \text { and } 90 \mathrm{Mg} \mathrm{ha}^{-1}\right) \text {. The precipitation was } \\
526 \mathrm{~mm} \text { and temperatures were close to } \\
\text { perennial values. Harvest by a rotary mower at } \\
\text { the end of September. }\end{array}$ & [108] \\
\hline & 15.4 & Czech Republic & $\begin{array}{l}\text { This average value of cup-plant is achieved in } \\
\text { long-term experiments under the same } \\
\text { agro-ecological conditions and conventional } \\
\text { agro-techniques. Harvested at the end of the } \\
\text { flowering period. }\end{array}$ & [15] \\
\hline & 11.2 & Czech Republic & $\begin{array}{l}\text { Different plants were tested, only under } \\
\text { experimental conditions, and only on a very } \\
\text { small scale; only several species have been } \\
\text { tested under field conditions. }\end{array}$ & [112] \\
\hline
\end{tabular}


Table 1. Cont.

\begin{tabular}{|c|c|c|c|c|}
\hline $\begin{array}{c}\text { Year of } \\
\text { Harvesting }\end{array}$ & $\begin{array}{c}\text { Yield } \\
\left(\mathrm{Mg} \mathrm{ha}^{-1} \mathrm{DM}\right)\end{array}$ & Country & Observations and Harvesting Details & Reference \\
\hline \multirow[t]{2}{*}{ Mean } & 15.5 & Germany & $\begin{array}{l}\text { The experimental fields were situated in two } \\
\text { different locations with } \mathrm{N} \text { and } \mathrm{P} \text { fertilizers } \\
\text { applied. Mean for six biomass traits over three } \\
\text { years (2014-2016). Plants were harvested each } \\
\text { year in August. }\end{array}$ & [52] \\
\hline & 13.2 & Lithuania & $\begin{array}{l}\text { Three different concentrations of fertilization } \\
\text { were used. Mean for the period between } 2009 \\
\text { and } 2014 \text {. Harvesting time: end of September. }\end{array}$ & [113] \\
\hline
\end{tabular}

\subsubsection{Biogas and Biomethane Yields}

Research conducted in the Czech Republic confirmed that biomass yields were the highest for Silphium perfoliatum and lower for maize, but the quality needed for biogas production is still higher for maize than for Silphium perfoliatum [15]. There are several studies that compared the biogas yields of maize and Silphium perfoliatum [116-118]. Maize is the most popular agricultural crop and shows the best results when used for biogas production, and it has frequently been used as a reference plant to compare different agricultural residues/crops [117]. Specific biogas yield (SBY) was studied by Siwek et al. [110], who investigated the effect of the planting type on some properties of Silphium perfoliatum. Thus, although the SBY was analyzed for the planting and sowing techniques, no significant results were obtained. They also tested the effect of the number of harvests per year on the biogas yield. It was found that following two harvests per year (June and October) in the second year of growing (the first harvest), the mean of SBY ranged from 484 to $490 \mathrm{NL} \mathrm{kg}^{-1} \mathrm{VS}$ (VS-volatile solids), and this value was $504 \mathrm{NL} \mathrm{kg}^{-1} \mathrm{VS}$ when the plants were harvested once a year (October). In the third year of growing (the second harvest), the values ranged from 485 to $502 \mathrm{NL} \mathrm{kg}^{-1} \mathrm{VS}$ and $502 \mathrm{NL} \mathrm{kg}^{-1} \mathrm{VS}$ for two harvests per year and one harvest per year, respectively [110]. Almost similar values were obtained by Tîtei et al. [51], who found that the gas-forming potential of organic dry matter (ODM) in Silphium perfoliatum silage was $471 \mathrm{NL} \mathrm{kg}^{-1}$ VS (52.4\%) of methane. However, in a two-harvest and a single-harvest system, the biogas yield per hectare was 11,076 and $7262 \mathrm{~m}^{3} \mathrm{ha}^{-1}$, respectively [110]. In some experiments, Silphium perfoliatum was used as a reference crop for biogas production as well as with maize. However, in this case, it was assumed that Silphium is less suitable for anaerobic digestion, which is indicated by the lower biogas yields compared to maize [117].

According to research conducted in Lithuania, the biogas volume obtained from Silphium perfoliatum can exceed $5000 \mathrm{~m}^{3} \mathrm{ha}^{-1}$ and contains $58.6 \%$ methane. It was also estimated that such an amount of biogas is equal to $113.0 \mathrm{GJ}$ of energy ha ${ }^{-1}$ [113]. One study in Germany focused on the impact of different harvest dates on biogas potential and found that MHY for Silphium perfoliatum may be higher if harvesting is performed earlier and the MHY was almost similar to the yields of maize and, in some cases, even higher than some perennial crops. Thus, the specific methane yield (SMY) in the total biogas yield was higher for Silphium perfoliatum (53.9\%) than for other perennial crops (energy dock Rumex schavnat-52.8\%, Szarvasi Elymus elongatus and Igniscum Falopia sachalinensis-53.2\%) and maize (52.6\% of methane) [14]. The methane content in biogas from the Silphium perfoliatum silage was higher $(56.3 \%)$ than in maize silage (55\%) [119]. The share of biomethane in biogas ranged from $51.1 \%$ to $52.9 \%$. The highest values were obtained in an earlier harvest in the summer (June) and were slightly lower for a harvest made later in the autumn (October) [110].

The biochemical methane potential (BMP) of Silphium perfoliatum was analyzed in another study in Germany. On average, the BMP was $260 \mathrm{NL} \mathrm{kg}^{-1} \mathrm{VS}$ [87], and it was almost $7.7 \%$ higher than in other previously published data, namely $251 \mathrm{NL} \mathrm{kg}^{-1}$ VS [120] and $252 \mathrm{NL} \mathrm{kg}^{-1}$ VS [14].

The medium gross energy yield for Silphium perfoliatum silage was $25.7 \mathrm{kWh} \mathrm{ha}^{-1}\left(92.5 \mathrm{GJ} \mathrm{ha}^{-1}\right)$ and was $46.5 \mathrm{kWh} \mathrm{ha}^{-1}$ lower, compared with the maize silage $\left(167.4 \mathrm{GJ} \mathrm{ha}^{-1}\right)$. Therefore, the conclusion 
was that the new energy crops (Silphium) cannot compete with the specific methane yield of maize [120], due to the high yields and low market prices of the latter.

It was found that lignin is a very important component of biomass intended for biogas production since it influences specific methane yields. With lower contents of a lignin and fiber fractions, higher methane yields can be obtained $[117,119]$.

Table 2 presents the values for SMY and MHY. The values differ when the crop is exposed to different factors, such as soil moisture, growing period and the number of harvests, or the type/origin of some varieties of Silphium. Even if Silphium perfoliatum is tolerant of drought, a reduction in water/rainfall reduces the methane yield per hectare $[13,118]$. The highest values for specific methane yield were estimated to be $321 \mathrm{NL} \mathrm{kg}^{-1} \mathrm{VS}$ and for methane hectare yield to be $5399 \mathrm{Nm}^{3} \mathrm{ha}^{-1}$ [13].

Table 2. The specific methane yield (SMY) and methane hectare yield (MHY) of Silphium perfoliatum in different studies.

\begin{tabular}{|c|c|c|c|c|}
\hline Country & $\begin{array}{l}\text { Specific Methane Yield } \\
\text { SMY (NL kg-1 VS) }\end{array}$ & $\begin{array}{l}\text { Methane Hectare Yield } \\
\text { MHY }\left(\mathrm{Nm}^{3} \mathrm{ha}^{-1}\right)\end{array}$ & Observations & Reference \\
\hline $\begin{array}{l}\text { Southern } \\
\text { Germany }\end{array}$ & $\begin{array}{c}232 * \\
275^{* * *}\end{array}$ & $\begin{array}{l}4301^{\mathrm{a}} \\
3318^{\mathrm{b}}\end{array}$ & $\begin{array}{l}\text { The highest and the lowest yields } \\
\text { obtained from four different } \\
\text { harvested batches, two doses of } \mathrm{N} \\
\text { fertilizer: } 80 \text { and } 100 \mathrm{~kg} \mathrm{ha}^{-1} \text {. }\end{array}$ & [14] \\
\hline Germany & $\begin{array}{l}236-2450 * \\
273-282 * *\end{array}$ & n.d. & $\begin{array}{l}\text { Different excess and non-excess soil } \\
\text { moisture were tested. Higher values } \\
\text { for excess moisture. }\end{array}$ & [87] \\
\hline Germany & $\begin{array}{l}290 *-303 * * \\
310 *-321 * *\end{array}$ & $\begin{array}{l}2889 *-3543 * * \\
4789 *-5399 * *\end{array}$ & $\begin{array}{l}\text { Rainfed and irrigated, first and } \\
\text { second-year harvest, respectively. }\end{array}$ & [13] \\
\hline $\begin{array}{l}\text { Southwest } \\
\text { Germany }\end{array}$ & 260 & 4856 & $\begin{array}{l}\text { Average for four years of harvesting } \\
\text { (2015-2018). The first year } \\
(2014 \text {, n.d.) was excluded from the } \\
\text { calculation of average. }\end{array}$ & [117] \\
\hline Czech Republic & 276 & 3921 & $\begin{array}{l}\text { Study based on long-term } \\
\text { experiments and mixed samples } \\
\text { with different fertilization rates. }\end{array}$ & [15] \\
\hline Germany & $258^{c}-273^{d}$ & $3697^{d}-4634^{c}$ & $\begin{array}{l}\text { Study of five countries of origin: } \\
\text { USA, East Germany, Russia, } \\
\text { Northern Europe, Ukraine over } \\
\text { three years without fertilizer and the } \\
\text { application of } 100-150 \mathrm{~kg} \mathrm{ha}^{-1} \mathrm{~N} \text {. }\end{array}$ & [52] \\
\hline
\end{tabular}

\subsection{Composition of Biomass and Chemical Characteristics}

The composition of Silphium biomass depends on many factors, such as species, variety, harvest period (months, vegetative period or after the end of the vegetative period), soil types and climatic factors. The crude protein content in the early vegetative stages is higher (13\% to $15 \% \mathrm{DM})$ than in the bud stage (10\% DM) and continues to decline at seed setting ( $5 \%$ to $8 \% \mathrm{DM})$, due to very low $\mathrm{N}$ level in the steams [27]. It was observed that higher protein content can be obtained in wet years than in those with low precipitation [28]. In another study, the crude protein content of Silphium perfoliatum in vegetation phases ranged from $4.9 \%$ to $8.5 \% \mathrm{DM}$, the content of crude fat ranged from $2.1 \%$ to $2.5 \% \mathrm{DM}$ and crude fiber from $23.1 \%$ to $29.7 \% \mathrm{DM}$. The hemicellulose content ranged from $5.4 \%$ $\mathrm{DM}$ at the vegetative phase to $10.1 \% \mathrm{DM}$ at the beginning of seed setting [121]. Another study reported similar results of the crude protein content of Silphium perfoliatum (end of flowering) of $7.5 \%$ DM, crude fat content of $2.6 \% \mathrm{DM}$, crude fiber content of $26.4 \% \mathrm{DM}$ and crude ash content of $8.0 \% \mathrm{DM}$ [15]. A detailed analysis of the biomass properties of Silphium perfoliatum and other crops harvested after the vegetation period (in February) was conducted by Stolarski et al. [122]. The raw Silphium perfoliatum biomass had the cellulose content of 51.8\% DM, the hemicellulose content of $20.3 \%$ DM and the lignin 
content of $11.5 \%$ DM. In the same study, the elemental composition of Silphium biomass was tested. It was found that the carbon content was $51.9 \% \mathrm{DM}$, the hydrogen content was $5.75 \% \mathrm{DM}$ and the nitrogen content was below $0.49 \% \mathrm{DM}$. The sulfur content was $0.043 \% \mathrm{DM}$ and for chlorine it was below $0.026 \%$ DM [122].

In a study conducted in Germany, the Silphium perfoliatum silage parameters were as follows: $27.1 \% \mathrm{DM}$, ODM 88.4\% DM, pH of silage at 5.1, lactic acid 4.2\% DM, acetic acid 1.9\% DM, butyric acid $1.2 \% \mathrm{DM}$ and alcohols $0.5 \%$ DM [119]. The chemical characteristics of Silphium perfoliatum silage were $42.5 \%$ DM for NFE (nitrogen-free extracts), $52.3 \%$ DM for NDF (neutral detergent fiber), $36.5 \%$ DM for ADF (acid detergent fiber), 7.9\% DM for ADL (acid detergent lignin) and the C:N ratio was 39 [119].

The lower heating value (LHV), moisture and ash content depend on the harvesting time of Silphium perfoliatum, while a higher heating value (HHV), carbon, hydrogen and sulfur contents are less influenced by this factor [57,123]. Jasinskas et al. [17] found that the highest HHV of Silphium perfoliatum was recorded in the third year of growing $\left(17.5 \mathrm{MJ} \mathrm{kg}^{-1} \mathrm{DM}\right)$ and it was higher than the two previous years. In another study, a slightly higher HHV (18.3 $\left.\mathrm{MJ} \mathrm{kg}^{-1} \mathrm{DM}\right)$ was reported [122]. However, in the studied literature, Stolarski et al. [5] obtained the highest HHV (18.8 $\left.\mathrm{MJ} \mathrm{kg}^{-1} \mathrm{DM}\right)$. This value was calculated as the mean for six consecutive months, starting from November. In the same study, the calculated mean of LHV for six months was $11.1 \mathrm{MJ} \mathrm{kg}^{-1} \mathrm{FM} \mathrm{[5].} \mathrm{In} \mathrm{a} \mathrm{recent} \mathrm{study} \mathrm{by} \mathrm{Stolarski}$ et al. [122], the LHV of Silphium perfoliatum raw biomass was higher (15.7 MJ kg-1 FM) because of a very low moisture content reaching $7.19 \%$. As an energy plant, Silphium was also investigated for the production of pellets and briquettes. Thus, it has been established that the pressure of compaction and moisture plays an important role in the process of pressing and forming the pellets. A moisture level of $8 \%$ and pressure of 262 MPa provide improved density and durability of Silphium pellets [102].

A recent study of the chemical composition of the Silphium genus, including Silphium perfoliatum, found that it is a valuable nutritional source, and it can compete with other forage crops. Moreover, Silphium perfoliatum offers the highest content of ash and phosphorus ( $7.82 \%$ and $0.35 \%$, respectively) [22]. A detailed amino acid profile has been evaluated in several studies. Figure 4 presents the mean amino acid profile $[46,81]$ obtained for the whole plant and the results obtained from leaves of Silphium perfoliatum [81]. It contains all types of amino acids which are important for use as a forage crop or extraction of some active compounds for a specific purpose. For some cases, leaves can contain a higher percentage of some components than whole plants, as shown in Figure 4. The content of cysteine was found to reach $0.8 \%$ in herbs (whole plant) [81], while an earlier publication [46] did not provide any data on this amino acid.

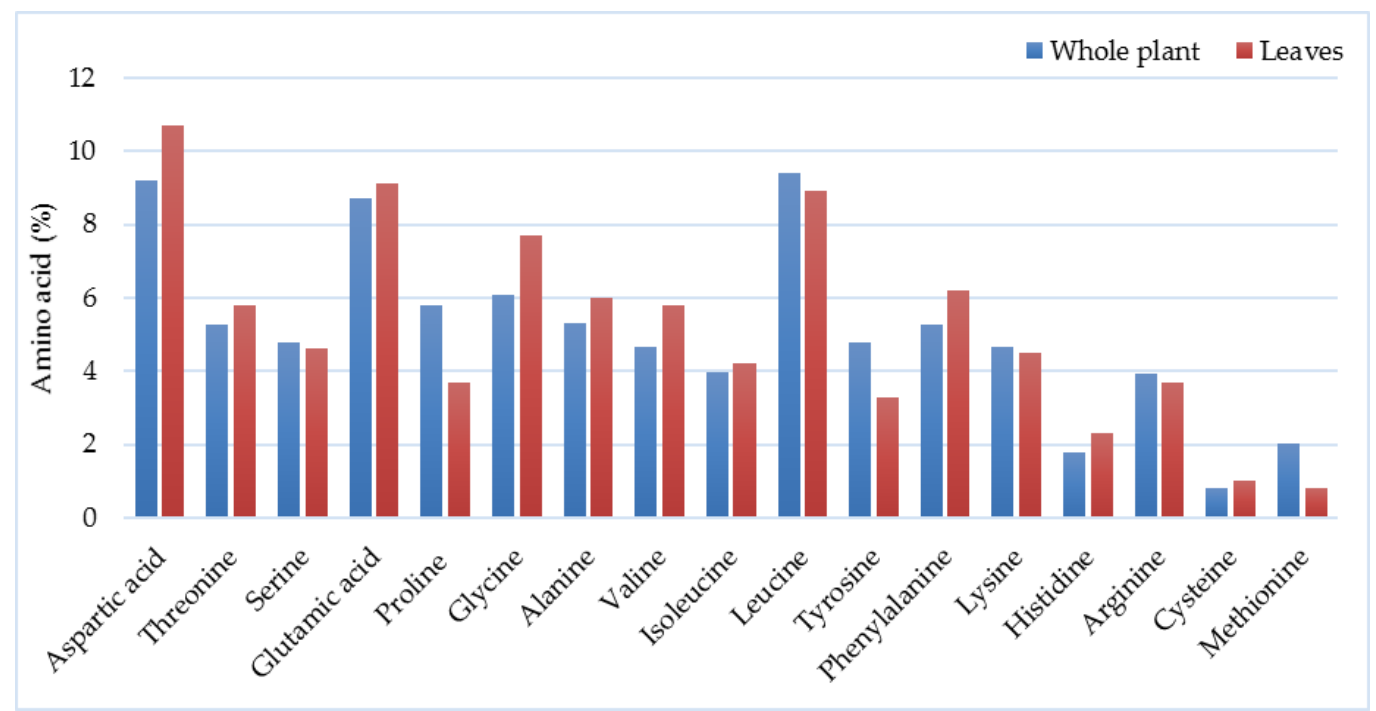

Figure 4. Percentage of amino acids from Silphium perfoliatum, compared to its leaves. Source: References [46,81]. 


\section{Economic Aspects and Energy Efficiency of Biomass Production}

Economic factors are very important in the use of Silphium perfoliatum as a feedstock for energy and other purposes. Since this plant is tolerant of unfavorable environmental conditions, it offers high biomass yields and the possibility of being planted on poor quality soils where other crops would be unprofitable. However, due to the high price of seedlings and the very high establishment costs for the farmers, Silphium perfoliatum cultivation is low and limited to small scale and trial plantations [124]. It was estimated that to be able to obtain reasonable yields, seed processing is necessary, which costs 1700 Euro per hectare. This operation is considered to be time- and cost-consuming due to the different and unequal seed size and maturity. The seed amount required per hectare is $2.5 \mathrm{~kg}$, whose market price is approximatively 680 Euro $\mathrm{kg}^{-1}$. Thus, the cultivation by seedlings can be replaced with sowing. To obtain a high yield level, sowing 1 ha with Silphium perfoliatum seeds is estimated to cost about 3150 Euro. This cost is estimated to be around $60 \%$ of the total costs of maintaining a plantation. If the plantation is used for ten years, these costs are divided to this period and total around 400 Euro per hectare per year. Of course, this cost may decrease if the plantation is operated for longer periods, such as 15 years (290 Euro per hectare per year) [125]. The cost of using Silphium perfoliatum as a feedstock for biogas production was discussed by Gerstberger et al. [84]. It was estimated that, together with additional compensation, the costs are almost the same as for maize crops [84]. Moreover, compared with maize fields, Silphium perfoliatum fields facilitate water infiltration and nutrient circulation [92] and are well-suited for the diversification of bioenergy farming landscapes $[84,85]$. Silphium perfoliatum may contribute to reducing the need for nitrogen fertilizers since its well-developed root system stops the leaching of nutrients from the soil. Thus, in subsequent years of growing, this plant may reduce the amount of fertilizers and prevent the contamination of waters with nitrogen due to reduced erosion [92]. To further reduce the costs, in some cases it was proposed to sow different crops, including forage crop [26,32] between plant rows for the first year of growing, when the Silphium perfoliatum biomass yields are significantly lower than in the following years [92].

Another important issue is the energy efficiency of Silphium perfoliatum biomass production. The goal is to obtain much higher energy output than energy input level in the biomass production of this species. The energy input depends on the production technology used. The amount of applied mineral fertilizers, mainly nitrogen fertilizers, is of particular importance. In studies conducted in Lithuania [54], the energy input for the cultivation of this species without mineral fertilization was $7.4 \mathrm{GJ} \mathrm{ha}^{-1}$ (Table 3). The use of liming and nitrogen fertilization increased these inputs up to $28 \mathrm{GJ} \mathrm{ha}^{-1}$, depending on the variant and the amount of fertilizers used. It must be stressed that the applied fertilization also increased the energy accumulated in biomass from 187.6 to $361.9 \mathrm{GJ} \mathrm{ha}^{-1}$ both with and without the highest fertilization doses, respectively. Therefore, the energy gain from biomass harvested at the end of September was high and ranged from 180.2 to $333.9 \mathrm{GJ} \mathrm{ha}^{-1}$, respectively. However, the energy ratio of Silphium perfoliatum biomass production was the highest (25.3) without fertilization, although this index was only 12.9 in the variant with the highest fertilization dose [54].

In other studies, in which Silphium perfoliatum was produced as a feedstock for solid biofuels for six years and the biomass was harvested at the end of March, the mean energy input was $8.1 \mathrm{GJ} \mathrm{ha}^{-1}$ (Table 4). The energy accumulated in the biomass increased from 82.3 to $184.4\left(\mathrm{GJ} \mathrm{ha}^{-1}\right)$ in the second and seventh years of cultivation, respectively, and the energy gain ranged from 74.7 to $175.3 \mathrm{GJ} \mathrm{ha}^{-1}$, respectively. The energy ratio of Silphium perfoliatum biomass production was the highest in the seventh year of cultivation (20.3). However, this index was only 10.8 in the second year of cultivation. In turn, the average energy ratio of cup plant cultivation as solid biofuel for six successive years was 13.5. In connection with the above, it should be stated that both energy gain and energy ratio increased significantly with the age of the plantation. Moreover, the accumulated energy in biomass and energy gain were higher when Silphium perfoliatum was harvested in September rather than in March [106]. 
Table 3. Energy-efficiency indicators of Silphium perfoliatum for different types and rates of fertilization, harvested at the end of September; based on Šiaudinis et al. [54].

\begin{tabular}{|c|c|c|c|c|}
\hline Fertilization Rate & $\begin{array}{l}\text { Energy Input } \\
\left(\mathrm{GJ} \mathrm{ha}^{-1}\right)\end{array}$ & $\begin{array}{l}\text { Energy Accumulated } \\
\left.\text { in Biomass (GJ ha }{ }^{-1}\right)\end{array}$ & $\begin{array}{l}\text { Energy Gain } \\
\left(\mathrm{GJ} \mathbf{h a}^{-1}\right)\end{array}$ & Energy Ratio \\
\hline N0 (not limed) & 7.4 & 187.6 & 180.2 & 25.3 \\
\hline N120 (not limed) & 17.2 & 299.4 & 282.2 & 17.4 \\
\hline $\mathrm{N} 0+0.5$ liming rate & 12.8 & 267.1 & 254.3 & 20.9 \\
\hline $\mathrm{N} 120+0.5$ liming rate & 22.6 & 290.5 & 267.9 & 12.9 \\
\hline $\mathrm{N} 0+1.0$ liming rate & 18.2 & 332.6 & 314.4 & 18.3 \\
\hline $\mathrm{N} 120+1.0$ liming rate & 28.0 & 361.9 & 333.9 & 12.9 \\
\hline
\end{tabular}

Table 4. Energy-efficiency indicators of Silphium perfoliatum production as feedstock for solid biofuels in six successive harvest rotations, harvested at the end of March; based on Stolarski et al. [106].

\begin{tabular}{|c|c|c|c|c|}
\hline Year/ Plantation Age & $\begin{array}{l}\text { Energy Input } \\
\quad\left(\mathrm{GJ} \mathrm{ha} \mathrm{a}^{-1}\right)\end{array}$ & $\begin{array}{l}\text { Energy Accumulated } \\
\text { in Biomass }\left(G J h^{-1}\right)\end{array}$ & $\begin{array}{l}\text { Energy Gain } \\
\left(\mathrm{GJ} \mathrm{ha}^{-1}\right)\end{array}$ & Energy Ratio \\
\hline $2012 / 2$ & 7.6 & 82.3 & 74.7 & 10.8 \\
\hline $2013 / 3$ & 8.2 & 93.2 & 85.0 & 11.4 \\
\hline $2014 / 4$ & 7.6 & 84.0 & 76.4 & 11.0 \\
\hline $2015 / 5$ & 7.9 & 99.3 & 91.5 & 12.7 \\
\hline $2016 / 6$ & 8.2 & 119.8 & 111.7 & 14.6 \\
\hline $2017 / 7$ & 9.1 & 184.4 & 175.3 & 20.3 \\
\hline Mean & 8.1 & 110.5 & 102.4 & 13.5 \\
\hline
\end{tabular}

\section{Conclusions}

The reviewed information about Silphium perfoliatum indicates that it can be used for different purposes, such as a fodder crop in Eastern Europe (Russia, Belarus and Ukraine) and China, as a renewable energy source in Central and Northeastern Europe (Germany, Czech Republic, Austria, Poland and Lithuania) and even as a promising competitor to maize for biogas production (Germany and Austria). It was interesting to find that different types/varieties and different environmental factors/features (different soil types, level of precipitations, drought and irrigation level) have been tested around the world.

It is necessary to investigate the possibility of cultivating Silphium on marginal and degraded soils, after extensive agriculture, that cannot be used for other crop plantations. In addition, long-term cultivation of Silphium perfoliatum will contribute to improving the soil quality, controlling erosion, improving water infiltration, enriching soil mineral compounds and enhancing biodiversity, especially regarding honeybees and other pollinators.

However, more studies are needed on the costs of maintaining a Silphium plantation for future possible large-scale implementation. It is well-known that cultivation by sowing rather than by seedlings can considerably reduce the cost of a Silphium perfoliatum plantation. It is very important to improve growing characteristics to obtain sufficient biomass yields to enable the replacement of a maize crop by Silphium perfoliatum for biogas production. Although the reviewed studies show that the use of fertilizers can improve biomass yields, these operations can generate other costs which reduce energy efficiency. Therefore, further long-term research is needed to evaluate the use of Silphium biomass in comparison with other substrates, taking into account the full cultivation cycle and economic, environmental and energy efficiency. The results of such studies would help to determine whether Silphium perfoliatum is competitive to other crops and which ecosystem services are the most important and the most reliable. 
Author Contributions: Conceptualization, M.J.S. and D.P.; methodology, M.J.S. and D.P.; formal analysis, M.K. and M.J.S.; validation, M.D., M.J.S. and M.K.; investigation, D.P., M.J.S. and A.B.; resources, M.J.S.; data curation, D.P. and M.J.S.; writing—original draft preparation, D.P., A.B., M.J.S. and M.K.; writing-review and editing, D.P., M.K. and M.J.S., A.B. and M.D.; visualization, D.P., A.B. and M.J.S.; supervision, M.J.S., M.D. and M.K.; funding acquisition, M.J.S. All authors have read and agreed to the published version of the manuscript.

Funding: This paper was co-financed by the National (Polish) Centre for Research and Development (NCBiR), entitled "Environment, agriculture and forestry", project BIOproducts from lignocellulosic biomass derived from MArginal land to fill the Gap in Current national bioeconomy, No. BIOSTRATEG3/344253/2/NCBR/2017. Dumitru Peni and Anna Bordiean are recipients of a scholarship from the Program of Interdisciplinary Doctoral Studies in Bioeconomy (POWR. 03.02.00-00-I034/16-00), which is funded by the European Social Fund.

Conflicts of Interest: The authors declare no conflict of interest.

\section{References}

1. Paolini, V.; Petracchini, F.; Segreto, M.; Tomassetti, L.; Naja, N.; Cecinato, A. Environmental impact of biogas: A short review of current knowledge. J. Environ. Sci. Health Part A 2018, 53, 899-906. [CrossRef]

2. Appels, L.; Baeyens, J.; Degreve, J.; Dewil, R. Principles and potential of the anaerobic digestion of waste-activated sludge. Prog. Energy Combust. Sci. 2008, 34, 755-781. [CrossRef]

3. Herrmann, A. Biogas production from maize: Current state, challenges and prospects. 2. Agronomic and environmental aspects. Bioenergy Res. 2013, 6, 372-387. [CrossRef]

4. Wu, X.; McLaren, J.; Madl, R.; Wang, D. Biofuels from Lignocellulosic Biomass. In Sustainable Biotechnology: Sources of Renewable Energy; Singh, O.V., Harvey, S.P., Eds.; Springer: Dordrecht, The Netherlands, 2010; pp. $19-41$.

5. Stolarski, M.J.; Krzyzaniak, M.; Snieg, M.; Slominska, E.; Piórkowski, M.; Filipkowski, R. Thermophysical and chemical properties of perennial energy crops depending on harvest period. Int. Agrophysics 2014, 28, 201-211. [CrossRef]

6. Romanowska-Duda, Z.; Grzesik, M.; Pszczółkowski, W.; Piotrowski, K.; Pszczółkowska, A. The didactic and environmental functions of the collection of energy crops in the transfer technology center in Konstantynów Łódzki. Acta Innov. 2014, 13, 37-48.

7. Van Tassel, D.L.; Albrecht, K.A.; Bever, J.D.; Boe, A.A.; Brandvain, Y.; Crews, T.E.; Gansberger, M.; Gerstberger, P.; González-Paleo, L.; Hulke, B.S. Accelerating Silphium domestication: An opportunity to develop new crop ideotypes and breeding strategies informed by multiple disciplines. Crop Sci. 2017, 57, 1274-1284. [CrossRef]

8. $\quad$ Landis, D.A.; Gratton, C.; Jackson, R.D.; Gross, K.L.; Duncan, D.S.; Liang, C.; Meehan, T.D.; Robertson, B.A.; Schmidt, T.M.; Stahlheber, K.A. Biomass and biofuel crop effects on biodiversity and ecosystem services in the North Central US. Biomass Bioenergy 2018, 114, 18-29. [CrossRef]

9. Langhammer, M.; Grimm, V. Mitigating bioenergy-driven biodiversity decline: A modelling approach with the European brown hare. Ecol. Model. 2020, 416, 108914. [CrossRef]

10. Fiedler, A.K.; Landis, D.A. Attractiveness of Michigan native plants to arthropod natural enemies and herbivores. Environ. Entomol. 2007, 36, 751-765. [CrossRef]

11. Gansberger, M.; Montgomery, L.F.R.; Liebhard, P. Botanical characteristics, crop management and potential of Silphium perfoliatum L. as a renewable resource for biogas production: A review. Ind. Crop. Prod. 2015, 63, 362-372. [CrossRef]

12. Gansberger, M.; Stüger, H.-P.; Weinhappel, M.; Moder, K.; Liebhard, P.; von Gehren, P.; Mayr, J.; Ratzenböck, A. Germination characteristic of Silphium perfoliatum L. seeds. Bodenkult. J. Land Manag. Food Environ. 2017, 68, 73-79. [CrossRef]

13. Schoo, B.; Kage, H.; Schittenhelm, S. Radiation use efficiency, chemical composition, and methane yield of biogas crops under rainfed and irrigated conditions. Eur. J. Agron. 2017, 87, 8-18. [CrossRef]

14. Mast, B.; Lemmer, A.; Oechsner, H.; Reinhardt-Hanisch, A.; Claupein, W.; Graeff-Hönninger, S. Methane yield potential of novel perennial biogas crops influenced by harvest date. Ind. Crop. Prod. 2014, 58, 194-203. [CrossRef]

15. Ustak, S.; Munoz, J. Cup-plant potential for biogas production compared to reference maize in relation to the balance needs of nutrients and some microelements for their cultivation. J. Environ. Manag. 2018, 228, 260-266. [CrossRef] [PubMed] 
16. Zhang, X.; Xia, H.; Li, Z.; Zhuang, P.; Gao, B. Potential of four forage grasses in remediation of Cd and Zn contaminated soils. Bioresour. Technol. 2010, 101, 2063-2066. [CrossRef]

17. Jasinskas, A.; Simonavičiūtè, R.; Šiaudinis, G.; Liaudanskienè, I.; Antanaitis, Š.; Arak, M.; Olt, J. The assessment of common mugwort (Artemisia vulgaris L.) and cup plant (Silphium perfoliatum L.) productivity and technological preparation for solid biofuel. Zemdirb. Agric. 2014, 101, 19-26. [CrossRef]

18. Stolarski, M.J.; Śnieg, M.; Krzyżaniak, M.; Tworkowski, J.; Szczukowski, S. Short rotation coppices, grasses and other herbaceous crops: Productivity and yield energy value versus 26 genotypes. Biomass Bioenergy 2018, 119, 109-120. [CrossRef]

19. Reinert, S.; Hulke, B.S.; Prasifka, J.R. Pest potential of Neotephritis finalis (Loew) on Silphium integrifolium Michx., Silphium perfoliatum L., and interspecific hybrids. Agron. J. 2020, 112, 1462-1465. [CrossRef]

20. Boe, A.; Albrecht, K.A.; Johnson, P.J.; Wu, J. Biomass Production of Cup Plant (Silphium perfoliatum L.) in Response to Variation in Plant Population Density in the North Central USA. Am. J. Plant Sci. 2019, 10, 904-910. [CrossRef]

21. Douglas, J.A.; Follett, J.M.; Halliday, I.R.; Hughes, J.W.; Parr, C.R. Silphium: Preliminary research on a possible new forage crop for New Zealand. Proc. Agron. Soc. N. Z. 1987, 17, 51-53.

22. Rakhmetov, D.B.; Vergun, O.M.; Stadnichuk, N.O.; Shymanska, O.V.; Rakhmetova, S.O.; Fishchenko, V.V. Biochemical study of plant raw material of Silphium L. SPP. in M.M. Gryshko National Botanical Garden of the NAS of Ukraine. Plant Introd. 2019, 83, 80-86. [CrossRef]

23. Han, K.J.; Albrecht, K.A.; Mertens, D.R.; Kim, D.A. Comparison of in vitro digestion kinetics of cup-plant and alfalfa. Asian-Australas. J. Anim. Sci. 2000, 13, 641-644. [CrossRef]

24. Han, K.J.; Albrecht, K.A.; Muck, R.E.; Kim, D.A. Moisture effect on fermentation characteristics of cup-plant silage. Asian-Australas. J. Anim. Sci. 2000, 13, 636-640. [CrossRef]

25. Puia, I.; Szabo, A.T. Experimental cultivation of a new forage species-Silphium perfoliatum L.-in the Agrobotanical Garden from Cluj-Napoca. Not. Bot. Horti Agrobot. Cluj-Napoca 1985, 15, 15-20.

26. Pastukhova, M.A.; Sheliuto, B.V. Возделываниесильфии пронзеннолистной под покровом сельскохозяйственных культур [Cultivation of Silphium perfoaliatum under agricultural crops cover]. Bull. Belarus. State Agric. Acad. 2019, 3, 83-87.

27. Pichard, G. Management, production, and nutritional characteristics of cup-plant (Silphium perfoliatum) in temperate climates of southern Chile. Cienc. Investig. Agrar. 2012, 39, 61-77. [CrossRef]

28. Guoyan, P.; Ouyang, Z.; Qunying, L.; Qiang, Y.; Jishun, W. Water consumption of seven forage cultivars under different climatic conditions in the North China plain. J. Resour. Ecol. 2011, 2, 74-82. [CrossRef]

29. Gimbatov, A.S.; Alimirzaeva, G.A. Optimization of technology for the cultivation of new feed crops in the irrigated conditions of the lowland zone of Dagestan. Probl. Dev. Agric. Ind. Apk Reg. 2011, 5, 8-11.

30. Zaynullina, K.S.; Ruban, G.A.; Mikhovich, J.E.; Portnyagina, N.V.; Potapov, A.A.; Punegov, V.V.; Fomina, M.G. Prospects of introduction in culture in the North some resource plants (Komi Republic). Bull. Samara Sci. Cent. Russ. Acad. Sci. 2015, 17, 121-126.

31. Novichikhin, A.M.; Piscareva, L.A. The study of elements of the cultivation technology of Silphium Perfoliatum. Symb. Sci. 2016, 10, 38-41.

32. Semerenko, M.V.; Chupina, M.P.; Stepanov, A.F. The influence of compacting crops on the productivity of perfoliate sylphs. Bull. Omsk State Agric. Univ. 2016, 2, 61-65.

33. Chupina, M.P.; Stepanov, A.F. The application of Silphium perfoliatum in the system of green and raw material conveyors. Agric. Sci. J. Omsk 2017, 4, 92-97.

34. Kowalski, R. Analysis of lipophilic fraction from leaves, inflorescences and rhizomes of Silphium perfoliatum L. Acta Soc. Bot. Pol. 2005, 74, 5-10. [CrossRef]

35. Kowalski, R.; Wierciński, J. Evaluation of chemical composition of some Silphium L. species seeds as alternative foodstuff raw materials. Pol. J. Food Nutr. Sci. 2004, 13, 349-354.

36. Danilov, K.P. The effect of the method and sowing rate on the yield of Silphium perfoliatum. News Orenbg. State Agrar. Univ. 2013, 4, 37-39.

37. Klímek, P.; Meinlschmidt, P.; Wimmer, R.; Plinke, B.; Schirp, A. Using sunflower (Helianthus annuus L.), topinambour (Helianthus tuberosus L.) and cup-plant (Silphium perfoliatum L.) stalks as alternative raw materials for particleboards. Ind. Crop. Prod. 2016, 92, 157-164. [CrossRef]

38. Pastukhova, M.A. The place of Silphium perfoliatum in the nectariferous conveyor in the conditions of the south-west of Belarus. Bull. Belarus. State Agric. Acad. 2019, 3, 88-92. 
39. Mueller, A.L.; Berger, C.A.; Schittenhelm, S.; Stever-Schoo, B.; Dauber, J. Water availability affects nectar sugar production and insect visitation of the cup plant Silphium perfoliatum L. (Asteraceae). J. Agron. Crop Sci. 2020, 206, 529-537. [CrossRef]

40. Mueller, A.L.; Biertümpfel, A.; Friedritz, L.; Power, E.F.; Wright, G.A.; Dauber, J. Floral resources provided by the new energy crop, Silphium perfoliatum L. (Asteraceae). J. Apic. Res. 2020, 59, 232-245. [CrossRef]

41. Savin, A.P.; Gudimova, N.A. The influence of mineral fertilizers on the nectar, forage and seed productivity sylphs standardized. Современные проблемы пчеловодства иапитерапии: монография/под, Рыбное:

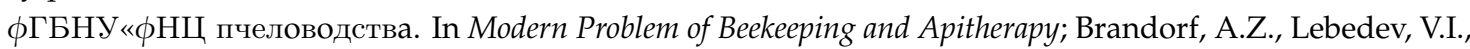
Kharitonova, M.N., Savina, A.P., Savushkina, L.N., Lizunova, A.S., Eds.; Publisher: Rybnoe, Russia, 2019; pp. 186-191.

42. Clevinger, J.A. New combinations in Silphium (Asteraceae: Heliantheae). Novon 2004, 14, $275-277$.

43. Clevinger, J.A.; Panero, J.L. Phylogenetic analysis of Silphium and subtribe Engelmanniinae (Asteraceae: Heliantheae) based on ITS and ETS sequence data. Am. J. Bot. 2000, 87, 565-572. [CrossRef] [PubMed]

44. Kowalski, R.; Kędzia, B. Antibacterial activity of Silphium perfoliatum. Extracts. Pharm. Biol. 2007, 45, 494-500. [CrossRef]

45. Assefa, T.; Wu, J.; Albrecht, K.A.; Johnson, P.J.; Boe, A. Genetic variation for biomass and related morphological traits in cup plant (Silphium perfoliatum L.). Am. J. Plant Sci. 2015, 6, 1098-1108. [CrossRef]

46. Țiţei, V.; Teleuţă, A.; Muntea, A. The perspective of cultivation and utilization of the species Silphium perfoliatum L. and Helianthus tuberosus L. Mold. Bull. UASMV Agric. 2013, 70, 160-166.

47. Tîței, V. Biological peculiarities of cup plant (Silphium perfoliatum L.) and utilization possibilities in the Republic of Moldova. Agron. Ser. Sci. Res. Lucr. Stiintifice Ser. Agron. 2014, 57, 289-293.

48. Feng, W.-S.; Pei, Y.-Y.; Zheng, X.-K.; Li, C.-G.; Ke, Y.-Y.; Lv, Y.-Y.; Zhang, Y.-L. A new kaempferol trioside from Silphium perfoliatum. J. Asian Nat. Prod. Res. 2014, 16, 393-399. [CrossRef]

49. Franzaring, J.; Holz, I.; Kauf, Z.; Fangmeier, A. Responses of the novel bioenergy plant species Sida hermaphrodita (L.) Rusby and Silphium perfoliatum L. to $\mathrm{CO}_{2}$ fertilization at different temperatures and water supply. Biomass Bioenergy 2015, 81, 574-583. [CrossRef]

50. Stanford, G. Silphium perfoliatum (cup-plant) as a new forage. In Proceedings of the Twelfth North American Prairie Conference: Recapturing a Vanishing Heritage, Cedar Falls, Iowa, 5-9 August 1990; pp. 33-37.

51. Tîţei, V. The evaluation of biomass of the Sida hermaphrodita and Silphium perfoliatum for renewable energy in Moldova. Sci. Pap. Ser. A Agron. 2017, 60, 534-540.

52. Wever, C.; Höller, M.; Becker, L.; Biertümpfel, A.; Köhler, J.; van Inghelandt, D.; Westhoff, P.; Pude, R.; Pestsova, E. Towards high-biomass yielding bioenergy crop Silphium perfoliatum L.: Phenotypic and genotypic evaluation of five cultivated populations. Biomass Bioenergy 2019, 124, 102-113. [CrossRef]

53. Shalyuta, B.V.; Kostitskaya, E.V. The yield of Silphium perfoliatum L. depending on the conditions of cultivation. Agric. Eng. 2018, 22, 91-97. [CrossRef]

54. Šiaudinis, G.; Jasinskas, A.; Šlepetienè, A.; Karčauskienė, D. The evaluation of biomass and energy productivity of common mugwort (Artemisia vulgaris L.) and cup plant (Silphium perfoliatum L.) in Albeluvisol. Agriculture 2012, 99, 357-362.

55. Šiaudinis, G.; Skuodienè, R.; Repšienè, R. The investigation of three potential energy crops: Common mugwort, cup plant and Virginia mallow on Western Lithuania's Albeluvisol. Appl. Ecol. Environ. Res. 2017, 15, 611-620. [CrossRef]

56. Assefa, T.; Wu, J.; Boe, A. Genetic variation for achene traits in cup plant (Silphium perfoliatum L.). Open J. Genet. 2015, 5, 71-82. [CrossRef]

57. Stolarski, M.J.; Śnieg, M.; Krzyżaniak, M.; Tworkowski, J.; Szczukowski, S.; Graban, Ł.; Lajszner, W. Short rotation coppices, grasses and other herbaceous crops: Biomass properties versus 26 genotypes and harvest time. Ind. Crop. Prod. 2018, 119, 22-32. [CrossRef]

58. Stankevich, S.I.; Kiselev, A.A.; Nesterenko, T.K. The influence of the method of spreading on productivity of cup plant. Bull. Belarusian State Agric. Acad. 2017, 3, 77-80.

59. Schäfer, A.; Meinhold, T.; Damerow, L.; Lammers, P.S. Crop establishment of Silphium perfoliatum by precision seeding. Agric. Eng. 2015, 70, 254-261. [CrossRef]

60. Schäfer, A.; Leder, A.; Graff, M.; Damerow, L.; Lammers, P.S. Determination and sorting of cup plant seeds to optimize crop establishment. Agric. Eng. 2018, 73, 97-105. 
61. Schäfer, A.; Damerow, L.; Lammers, P.S. Determination of the seed geometry of cup plant as requirement for precision seeding. Agric. Eng. 2017, 72, 122-129.

62. Tomaszewska-Sowa, M.; Figas, A. Optimization of the processes of sterilization and micropropagation of cup plant (Silphium perfoliatum L.) from apical explants of seedlings in in vitro cultures. Acta Agrobot. 2011, 64, 3-10. [CrossRef]

63. Figas, A.; Rolbiecki, R.; Tomaszewska-Sowa, M. Influence of drip irrigation on the height of cup plant (Silphium perfoliatum L.) cultivated on the very light soil from the micropagation seedlings. Infrastruct. Ecol. Rural Areas 2011, 10, 245-253.

64. Figas, A.; Rolbiecki, R.; Tomaszewska-Sowa, M. Influence of drip irrigation on the height of the biennial cup plant (Silphium perfoliatum L.) from the micropropagation seedlings. Infrastruct. Ecol. Rural Areas 2015, 3, 779-786. [CrossRef]

65. Figas, A.; Sawilska, A.K.; Rolbiecki, R.; Tomaszewska-Sowa, M. Morphological characteristics of achenes and fertility plants of cup plant (Silphium perfoliatum L.) obtained from micropropagation growing under irrigation. Infrastruct. Ecol. Rural Areas 2016, 4, 1363-1372. [CrossRef]

66. Figas, A.; Siwik-Ziomek, A.; Rolbiecki, R. Effect of irrigation on some growth parameters of cup plant and dehydrogenase activity in soil. Ann. Wars. Univ. Life Sci. Land Reclam. 2015, 47, 279-288. [CrossRef]

67. Oleszek, M.; Kowalska, I.; Oleszek, W. Phytochemicals in bioenergy crops. Phytochem. Rev. 2019, 18, 893-927. [CrossRef]

68. Kowalski, R.; Wolski, T. The chemical composition of essential oils of (Silphium perfoliatum L.). Flavour Fragr. J. 2005, 20, 306-310. [CrossRef]

69. Von Gehren, P.; Gansberger, M.; Mayr, J.; Liebhard, P. The effect of sowing date and seed pretreatments on establishment of the energy plant Silphium perfoliatum by sowing. Seed Sci. Technol. 2016, 44, 310-319. [CrossRef]

70. Guo, Y.; Shang, H.; Zhao, J.; Zhang, H.; Chen, S. Enzyme-assisted extraction of a cup plant (Silphium perfoliatum L.) Polysaccharide and its antioxidant and hypoglycemic activities. Process Biochem. 2020, 92, 17-28. [CrossRef]

71. Piszczek, P.; Kuszewska, K.; Błaszkowski, J.; Sochacka-Obruśnik, A.; Stojakowska, A.; Zubek, S. Associations between root-inhabiting fungi and 40 species of medicinal plants with potential applications in the pharmaceutical and biotechnological industries. Appl. Soil Ecol. 2019, 137, 69-77. [CrossRef]

72. Tomaszewska-Sowa, M.; Figas, A. Environmental and ecological aspects of cultivation of selected energy and herbal plants propagated by in vitro culture. Infrastruct. Ecol. Rural Areas 2014, 4, 1457-1465. [CrossRef]

73. Davidyants, E.S. The effect of the purified amount of triterpene glycosides and their enriched extract from leaves of Silphium perfoliatum L. on the growth and activity of nitrate reductase of winter wheat plants. Chem. Plant Raw Mater. 2019, 4, 441-448. [CrossRef]

74. El-Sayed, N.H.; Wojcińska, M.; Drost-Karbowska, K.; Matławska, I.; Williams, J.; Mabry, T.J. Kaempferol triosides from Silphium perfoliatum. Phytochemistry 2002, 60, 835-838. [CrossRef]

75. Jemiołkowska, A.; Kowalski, R. In vitro estimate of influence of Silphium perfoliatum L. leaves extract on some fungi colonizing the pepper plants. Acta Sci. Pol. Hort. Cult 2012, 11, 43-55.

76. Wu, H.; Shang, H.; Guo, Y.; Zhang, H.; Wu, H. Comparison of different extraction methods of polysaccharides from cup plant (Silphium perfoliatum L.). Process Biochem. 2020, 90, 241-248. [CrossRef]

77. Kowalski, R.; Wolski, T. Evaluation of phenolic acid content in Silphium perfoliatum L. leaves, inflorescences and rhizomes. Electron. J. Pol. Agric. Univ. 2003, 6, 1-10.

78. Shang, H.-M.; Zhou, H.-Z.; Li, R.; Duan, M.-Y.; Wu, H.-X.; Lou, Y.-J. Extraction optimization and influences of drying methods on antioxidant activities of polysaccharide from cup plant (Silphium perfoliatum L.). PLoS ONE 2017, 12, e0183001. [CrossRef] [PubMed]

79. Wolski, T.; Kowalski, R.; Mardarowicz, M. Chromatographic analysis of essential oil occurring in inflorescences, leaves and rhizomes of Silphium perfoliatum L. Herba Pol. 2000, 46, 235-242.

80. Kowalski, R. Silphium L. extracts-composition and protective effect on fatty acids content in sunflower oil subjected to heating and storage. Food Chem. 2009, 112, 820-830. [CrossRef]

81. Kowalska, G.; Pankiewicz, U.; Kowalski, R. Evaluation of Chemical Composition of Some Silphium L. Species as Alternative Raw Materials. Agriculture 2020, 10, 132. [CrossRef]

82. Tîţei, V. The potential growth and the biomass quality of some herbaceous species for the production of renewable energy in Moldova. Rev. Bot. Bot. J. 2019, 18, 83-91. 
83. Mueller, A.L.; Dauber, J. Hoverflies (Diptera: Syrphidae) benefit from a cultivation of the bioenergy crop Silphium perfoliatum L. (Asteraceae) depending on larval feeding type, landscape composition and crop management. Agric. For. Entomol. 2016, 18, 419-431. [CrossRef]

84. Gerstberger, P.; Asen, F.; Hartmann, C. Economy and ecology of cup plant (Silphium perfoliatum L.) compared with silage maize. J. Kult. 2016, 68, 372-377. [CrossRef]

85. Schorpp, Q.; Schrader, S. Earthworm functional groups respond to the perennial energy cropping system of the cup plant (Silphium perfoliatum L.). Biomass Bioenergy 2016, 87, 61-68. [CrossRef]

86. Schorpp, Q.; Schrader, S. Dynamic of nematode communities in energy plant cropping systems. Eur. J. Soil Biol. 2017, 78, 92-101. [CrossRef]

87. Ruf, T.; Emmerling, C. Site-adapted production of bioenergy feedstocks on poorly drained cropland through the cultivation of perennial crops. A feasibility study on biomass yield and biochemical methane potential. Biomass Bioenergy 2018, 119, 429-435. [CrossRef]

88. Ruf, T.; Makselon, J.; Udelhoven, T.; Emmerling, C. Soil quality indicator response to land-use change from annual to perennial bioenergy cropping systems in Germany. GCB Bioenergy 2018, 10, 444-459. [CrossRef]

89. Chmelíková, L.; Wolfrum, S. Mitigating the biodiversity footprint of energy crops-A case study on arthropod diversity. Biomass Bioenergy 2019, 125, 180-187. [CrossRef]

90. Ruf, T.; Audu, V.; Holzhauser, K.; Emmerling, C. Bioenergy from periodically waterlogged cropland in Europe: A first assessment of the potential of five perennial energy crops to provide biomass and their interactions with soil. Agronomy 2019, 9, 374. [CrossRef]

91. Schoo, B.; Schroetter, S.; Kage, H.; Schittenhelm, S. Root traits of cup plant, maize and lucerne grass grown under different soil and soil moisture conditions. J. Agron. Crop Sci. 2017, 203, 345-359. [CrossRef]

92. Grunwald, D.; Panten, K.; Schwarz, A.; Bischoff, W.A.; Schittenhelm, S. Comparison of maize, permanent cup plant and a perennial grass mixture with regard to soil and water protection. GCB Bioenergy 2020, 12, 694-705. [CrossRef]

93. Schorpp, Q.; Riggers, C.; Lewicka-Szczebak, D.; Giesemann, A.; Well, R.; Schrader, S. Influence of Lumbricus terrestris and Folsomia candida on $\mathrm{N}_{2} \mathrm{O}$ formation pathways in two different soils-With particular focus on $\mathrm{N}_{2}$ emissions. Rapid Commun. Mass Spectrom. 2016, 30, 2301-2314. [CrossRef]

94. Šiaudinis, G.; Liaudanskiene, I.; Slepetiene, A. Changes in soil carbon, nitrogen and sulphur content as influenced by liming and nitrogen fertilization of three energy crops. Icel. Agric. Sci. 2017, 30, 43-50. [CrossRef]

95. Bufe, C.; Korevaar, H. Evaluation of Additional Crops for Dutch List of Ecological Focus Area: Evaluation of Miscanthus, Silphium perfoliatum, Fallow Sown in with Melliferous Plants and Sunflowers in Seed Mixtures for Catch Crops; Report/WPR, no. 793; Wageningen Research Foundation (WR) Business Unit Agrosystems Research: Lelystad, The Netherlands, 2018; p. 34. [CrossRef]

96. Bedlan, G. Ascochyta silphii sp. nov.-A new Ascochyta species on Silphium perfoliatum. J. Kult. 2014, 66, 281-283. [CrossRef]

97. Balezentiene, L.; Streimikiene, D.; Balezentis, T. Fuzzy decision support methodology for sustainable energy crop selection. Renew. Sustain. Energy Rev. 2013, 17, 83-93. [CrossRef]

98. Antonkiewicz, J.; Jasiewicz, C. Effect of Soil Contamination with Heavy Metals on Element Contents in Silphium perfoliatum (Silphium perfoliatum L.). Chem. Ecol. Eng. 2003, 10, 205-210.

99. Du, J.; Zhang, L.; Ali, A.; Li, R.; Xiao, R.; Guo, D.; Liu, X.; Zhang, Z.; Ren, C.; Zhang, Z. Research on thermal disposal of phytoremediation plant waste: Stability of potentially toxic metals (PTMs) and oxidation resistance of biochars. Process Saf. Environ. Prot. 2019, 125, 260-268. [CrossRef]

100. Šiaudinis, G.; Jasinskas, A.; Šarauskis, E.; Steponavičius, D.; Karčauskienė, D.; Liaudanskienė, I. The assessment of Virginia mallow (Sida hermaphrodita Rusby) and cup plant (Silphium perfoliatum L.) productivity, physico-mechanical properties and energy expenses. Energy 2015, 93, 606-612. [CrossRef]

101. Wrobel, M.; Frączek, J.; Francik, S.; Slipek, Z.; Mudryk, K. Influence of degree of fragmentation on chosen quality parameters of briquette made from biomass of cup plant Silphium perfoliatum L. In Proceedings of the 12th International Scientific Conference Engineering for Rural Development, Jelgava, Latvia, 23-24 May 2013; pp. 653-657.

102. Styks, J.; Wróbel, M.; Frączek, J.; Knapczyk, A. Effect of Compaction Pressure and Moisture Content on Quality Parameters of Perennial Biomass Pellets. Energies 2020, 13, 1859. [CrossRef] 
103. Bury, M.; Facciotto, G.; Chiocchini, F.; Cumplido-Marín, L.; Graves, A.; Kitczak, T.; Martens, R.; Morhart, C.; Możdżer, E.; Nahm, M. Preliminary results regarding yields of Virginia mallow (Sida hermaphrodita L. Rusby) and cup plant (Silphium perfoliatum L.) in different condition of Europe. In Proceedings of the 27th European Biomass Conference and Exhibition, Lisbon, Portugal, 27-30 May 2019; pp. 101-104. [CrossRef]

104. Von Cossel, M.; Wagner, M.; Lask, J.; Magenau, E.; Bauerle, A.; Von Cossel, V.; Warrach-Sagi, K.; Elbersen, B.; Staritsky, I.; Van Eupen, M. Prospects of bioenergy cropping systems for a more social-ecologically sound bioeconomy. Agronomy 2019, 9, 605. [CrossRef]

105. Jucsor, N.; Sumalan, R. Researches concerning the potential of biomass accumulation in cup plant (Silphium perfoliatum L.). J. Hortic. For. Biotechnol. 2018, 22, 34-39.

106. Stolarski, M.J.; Krzyżaniak, M.; Warmiński, K.; Olba-Zięty, E.; Penni, D.; Bordiean, A. Energy efficiency indices for lignocellulosic biomass production: Short rotation coppices versus grasses and other herbaceous crops. Ind. Crop. Prod. 2019, 135, 10-20. [CrossRef]

107. Franzaring, J.; Schmid, I.; Bäuerle, L.; Gensheimer, G.; Fangmeier, A. Investigations on plant functional traits, epidermal structures and the ecophysiology of the novel bioenergy species Sida hermaphrodita Rusby and Silphium perfoliatum L. J. Appl. Bot. Food Qual. 2014, 87, 36-45. [CrossRef]

108. Šiaudinis, G.; Karčauskienè, D.; Aleinikovienè, J. Assessment of a single application of sewage sludge on the biomass yield of Silphium perfoliatum and changes in naturally acid soil properties. Agriculture 2019, 106, 213-218. [CrossRef]

109. Šiaudinis, G.; Skuodienè, R.; Katutis, K. Biomass and energy productivity of different plant species under western Lithuania conditions. In Proceedings of the 25th Nordic View to Sustainable Rural Development Congress, Riga, Latvia, 16-18 June 2015; pp. 232-237.

110. Siwek, H.; Włodarczyk, M.; Możdżer, E.; Bury, M.; Kitczak, T. Chemical Composition and Biogas Formation potential of Sida hermaphrodita and Silphium perfoliatum. Appl. Sci. 2019, 9, 4016. [CrossRef]

111. Boe, A.; Albrecht, K.A.; Johnson, P.J.; Wu, J. Biomass production of monocultures and mixtures of cup plant and native grasses on prime and marginal cropland. Am. J. Plant Sci. 2019, 10, 911. [CrossRef]

112. Heneman, P.; Červinka, J. Energy crops and bioenergetics in the Czech Republic. Agric. (Agric. Eng.) 2007, $51,73-78$.

113. Skorupskaitè, V.; Makarevičienè, V.; Šiaudinis, G.; Zajančauskaitè, V. Green energy from different feedstock processed under anaerobic conditions. Agron. Res. 2015, 13, 420-429.

114. Slepetys, J.; Kadziuliene, Z.; Sarunaite, L.; Tilvikiene, V.; Kryzeviciene, A. Biomass potential of plants grown for bioenergy production. In Proceedings of the Renewable Energy and Energy Efficiency, Growing and Processing Technologies of Energy Crops, Jelgava, Latvia, 2012; pp. 66-72. Available online: https://www.semanticscholar.org/paper/Biomass-potential-of-plants-grown-for-bioenergy-\%C5\% A0lepetys-Kadz\%CC\%8Ciuliene\%CC\%87/3d0f87eb3d601ee7472c9eca3abfe8f895c0c009?p2df (accessed on 4 December 2020).

115. Šiaudinis, G.; Šlepetienè, A.; Karčauskienè, D. The evaluation of dry mass yield of new energy crops and their energetic parameters. In Proceedings of the Renewable Energy and Energy Efficiency, Growing and Processing Technologies of Energy Crops, Jelgava, Latvia, 2012; pp. 24-28. Available online: https: //www.db-thueringen.de/receive/dbt_mods_00024401 (accessed on 4 December 2020).

116. Von Cossel, M.; Amarysti, C.; Wilhelm, H.; Priya, N.; Winkler, B.; Hoerner, L. The replacement of maize (Zea mays L.) by cup plant (Silphium perfoliatum L.) as biogas substrate and its implications for the energy and material flows of a large biogas plant. Biofuels Bioprod. Biorefining 2020, 14, 152-179. [CrossRef]

117. Von Cossel, M.; Steberl, K.; Hartung, J.; Pereira, L.A.; Kiesel, A.; Lewandowski, I. Methane yield and species diversity dynamics of perennial wild plant mixtures established alone, under cover crop maize (Zea mays L.), and after spring barley (Hordeum vulgare L.). GCB Bioenergy 2019, 11, 1376-1391. [CrossRef]

118. Schittenhelm, S.; Schoo, B.; Schroetter, S. Yield physiology of biogas plants: Comparison of streaky Silphie, maize and Luzernegra. J. Kult. 2016, 68, 378-384. [CrossRef]

119. Herrmann, C.; Idler, C.; Heiermann, M. Biogas crops grown in energy crop rotations: Linking chemical composition and methane production characteristics. Bioresour. Technol. 2016, 206, 23-35. [CrossRef]

120. Haag, N.L.; Nägele, H.-J.; Reiss, K.; Biertümpfel, A.; Oechsner, H. Methane formation potential of cup plant (Silphium perfoliatum). Biomass Bioenergy 2015, 75, 126-133. [CrossRef]

121. Majtkowski, W.; Piłat, J.; Szulc, P.M. Prospects of cultivation and utilization of Silphium perfoliatum L. in Poland. Biul. Inst. Hod. I Aklim. Roślin 2009, 251, 283-291. 
122. Stolarski, M.J.; Warmiński, K.; Krzyżaniak, M.; Tyśkiewicz, K.; Olba-Zięty, E.; Graban, Ł.; Lajszner, W.; Załuski, D.; Wiejak, R.; Kamiński, P. How does extraction of biologically active substances with supercritical carbon dioxide affect lignocellulosic biomass properties? Wood Sci. Technol. 2020, 54, 519-546. [CrossRef]

123. Stolarski, M.; Szczukowski, S.; Tworkowski,J. Biofuels from biomass of perennial energy crops. Energetyka Ekol. 2008, 1, 77-80.

124. Trölenberg, S.D.; Kruse, M.; Jonitz, A. Improvement of the seed quality in the Streaky Silphie (Silphium perfoliatum L.). In Nachhaltigkeitsindikatoren für die Landwirtschaft: Bestimmung und Eignung, VDLUFA-Schriftenreihe. Presented at the 124th VDLUFA-Kongress; VDLUFA-Verlag: Darmstadt, Germany, 2012; pp. 926-933.

125. Biertümpfel, A.; Conrad, M. (Eds.) Joint Project: Increase of the Performance Potential and the Competitiveness of the Streaky Silphie as an Energy Plant through Breeding and Optimization of the Cultivation Method: Subproject 2: Optimization of the Cultivation Method and Provision of Selection Material; Abschlussbericht; Project no. 99.05; FKZ; no.: 22012809; Friedrich-Schiller-Universität Jena: Jena, Germany, 2014.

Publisher's Note: MDPI stays neutral with regard to jurisdictional claims in published maps and institutional affiliations.

(C) 2020 by the authors. Licensee MDPI, Basel, Switzerland. This article is an open access article distributed under the terms and conditions of the Creative Commons Attribution (CC BY) license (http://creativecommons.org/licenses/by/4.0/). 